\title{
Brackish-Water Ostracoda (Crustacea) from the Obitsu River Estuary, Central Japan
}

\author{
Yuriko Nakao and Akira Tsukagoshi \\ Institute of Geosciences, Faculty of Science, Shizuoka University, \\ Oya 836, Shizuoka, 422-8529 Japan
}

(Received 7 May 2001; Accepted 26 October 2001)

\begin{abstract}
The brackish-water ostracod fauna was surveyed for almost two years at 17 points representing typical environments, such as foreshore sand flat, back marsh, and tidal creek, in the intertidal zone of the Obitsu River Estuary, Chiba Prefecture, central Japan. Twenty-one species belonging to 17 genera and 10 families were identified. In addition to the description of one new genus, Palusleptocythere, and four new species, Pontocythere xiphoidea, Palusleptocythere migrans, Loxoconcha kosugii, and Cytherois ikeyai, chitinous parts are described for the first time for four previously described species, Spinileberis pulchra Chen, 1982, Angulicytherura? miii (Ishizaki, 1969), Semicytherura wakamurasaki Yajima, 1982, and Loxoconcha pulchra Ishizaki, 1968. Furthermore chitinous parts of male Dolerocypria mukaishimensis Okubo, 1980 are also shown for the first time. This is the first report on an ostracod fauna from a shallow estuarine environment in either Japan or any adjacent area.
\end{abstract}

Key Words: Crustacea, Ostracoda, brackish-water, estuary, taxonomy, Tokyo Bay.

\section{Introduction}

Many descriptive studies on brackish-water ostracods from inner bay areas in Japan have been published since the 1960s: Uranouchi Bay (Ishizaki 1968), Lakes Shinji-ko and Nakanoumi (Ishizaki 1969), Aomori Bay (Ishizaki 1971), Lake Hamana (Ikeya and Hanai 1982; Ikeya et al. 1985), Ise Bay (Bodergat and Ikeya 1988), Toyama Bay (Ishizaki and Irizuki 1990), Sendai Bay (Ikeya and Itoh 1991), Otsuchi Bay (Ikeya et al. 1992; Tanaka et al. 1998), and Hiuchi-nada Bay (Yamane 1998). In these studies, the water depths of the examined materials were all greater than several meters, because the samples were collected by dredging and coring from ships. In general, the purpose of these studies was to present indices of brackish-water species useful for the reconstruction of paleoenvironments, rather than to describe the extant ostracod fauna. As a result, descriptions of Japanese brackish-water ostracods have emphasized carapace morphology, which is preserved in fossils, and tended to omit appendage descriptions. The lack of information on soft parts frequently makes the identification of extant species difficult.

Environments of less than a few meters depth have not previously been regarded as important sedimentary provinces in Japan; paleontological interests have concentrated on inner bay environments deeper than the intertidal zone. An- 


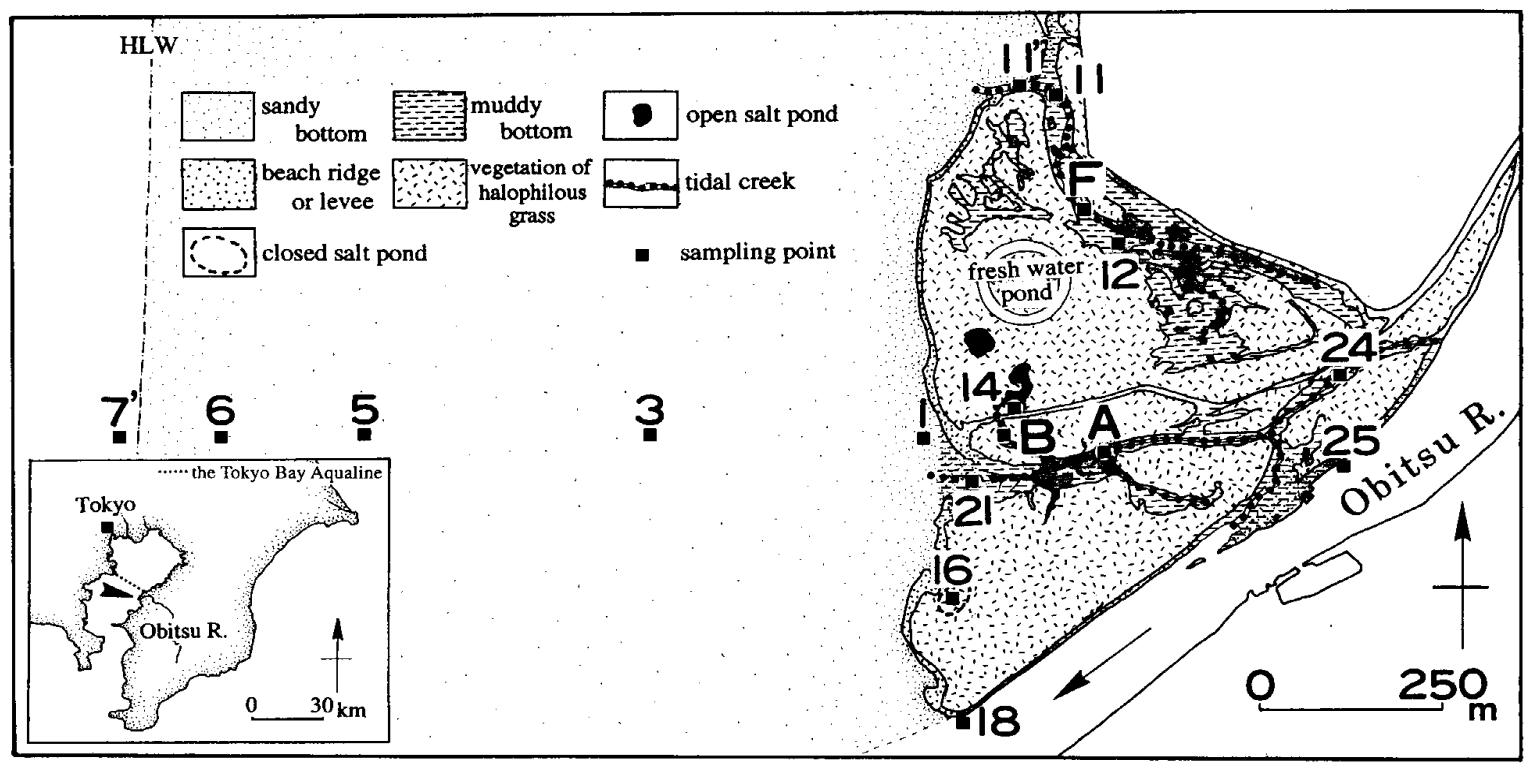

Fig. 1. Location and sediment distribution of the study area with sampling points for ostracods. Muddy bottom areas become submerged during high tide. [Adopted from Tsukagoshi 1994]

other reason for the lack of information on shallow brackish ostracod faunas is the rapid and major destruction of natural seacoast environments in Japan. For half a century, the seacoasts have been subjected to man-induced change on a large scale. Brackish-water environments are the first target of marine reclamation. As a result, lagoons and swamplands in Japan have disappeared as cities and industrial areas have rapidly grown, making the detailed documentation of many localities and their faunas difficult, if not impossible.

The lower reaches of the Obitsu River constitute the only remaining natural estuarine locality in the metropolitan area around Tokyo. This area has many of the characteristic geographic features of a natural estuary, e.g., sand flats, dunes, back swamps, and tidal creeks. Along the opposite side of Japan, the Sea of Japan coast is relatively unexploited, but natural features such as these cannot develop because of the small difference between low and high tide levels there. Therefore, the almost completely preserved estuarine character of the Obitsu River is now very rare in central Japan; as a consequence, it offers a source of valuable data.

The present taxonomic paper begins to make up for the lack of information on intertidal brackish-water ostracod faunas in Japan, and it should also prove useful for studies involving the reconstruction of paleoenvironments. Recently, a number of studies of Holocene deposits in Japan, which mostly consist of brackish-water sediments, have been carried out (Ishizaki 1984; Ikeya et al. 1987; Kamiya and Nakagawa 1993; Tsukagoshi et al. 1994; Ikeya 1995; Irizuki et al. 1998). The need for descriptions of ostracod faunas from equivalent modern environments has been urgently noted by researchers working on Quaternary paleoecology. The present paper will satisfy this lack in part, and it will also provide a baseline record of this changeable and delicate environment, against which future surveys may be compared. 


\section{Study Area and Materials}

The Obitsu River originates in the central Boso Peninsula and flows into Tokyo Bay. In the center of the study area, a beach ridge ( $c a 2.5 \mathrm{~m}$ above sea level) runs north-south and creates a boundary between the foreshore and the back swamp. The foreshore is more than $1 \mathrm{~km}$ wide and its western edge adjoins the front of a delta in the sublittoral zone. The back swamp consists of salt ponds, muddy tidal creeks, and vegetation of halophilous grass. Some salt ponds are closed while others are open, connected to the foreshore through tidal creeks during the high tide. A natural levee is developed along the northern side of the main stream of the Obitsu River. The maximum tidal amplitude is approximate $200 \mathrm{~cm}$ and this occurs in spring.

The material collected for the present study was surficial sediment from the uppermost $5 \mathrm{~mm}$ of the active layer. Sampling was carried out during low tide on alternate months from November, 1997 to September 1998. Seventeen points were selected as representative localities in the estuary (Fig. 1). At sampling points where the water depth was less than $20 \mathrm{~cm}$, the upper layer of sediment was scooped into a plastic bottle using a spoon (a flat spoon of $12 \times 15 \mathrm{~cm}$ or a rectangular spoon of $4 \times 7 \mathrm{~cm}$, depending on the degree of surface irregularity). A dustpan with a long handle and a plankton net were used for collecting sediment at points where the water depth was more than $20 \mathrm{~cm}$. Sediment samples were collected $200 \mathrm{cc}$ each from every locality. The sediment type and salinity at each sampling point are shown in Table 1 . Salinity was measured by an electric salinometer (HORIBA, SH-7) while collecting samples at low tide. Lists of ostracod species occurring in the study area and their densities in May and July are shown in Tables 3 and 4, respectively. Size dimensions, site of occurrence, and SRDP's of all species

Table 1. Bottom sediment and salinity at each sampling locality.

\begin{tabular}{clcl}
\hline Locality No. & Bottom sediment & Salinity $(\%)^{*}$ & \multicolumn{1}{c}{ Remarks } \\
\hline 1 & medium sand & $>20$ & tidal flat \\
3 & medium sand & $c a 25$ & tidal flat \\
5 & medium sand & $c a 25$ & tidal flat \\
6 & medium sand & $c a 25$ & tidal flat \\
7 & fine to medium sand & $c a 25$ & edge of tidal flat \\
11 & sandy mud & $c a 20$ & tidal creek \\
11 & medium sand & $c a 20$ & tidal creek \\
12 & mud & $22-30$ & tidal flat \\
14 & mud & $2-25$ & opened salt pond \\
16 & mud & $8-24$ & closed salt pond \\
18 & medium sand & $6-19$ & slope of tidal bank \\
21 & sandy mud & $9-24$ & mouth of branch stream \\
24 & sandy mud & $6-21$ & branch stream \\
25 & muddy sand & $>3$ & main stream of the river \\
A & mud & $7-23$ & branch stream \\
B & sandy mud & $4-25$ & waterway from salt pond \\
F & silty mud & $22-27$ & tidal flat \\
\hline
\end{tabular}

* The salinity at each locality was measured at around the time of lowest low tide. The values were influenced by rainfall. 
Table 2. Classification of 21 ostracod species found in the study area.

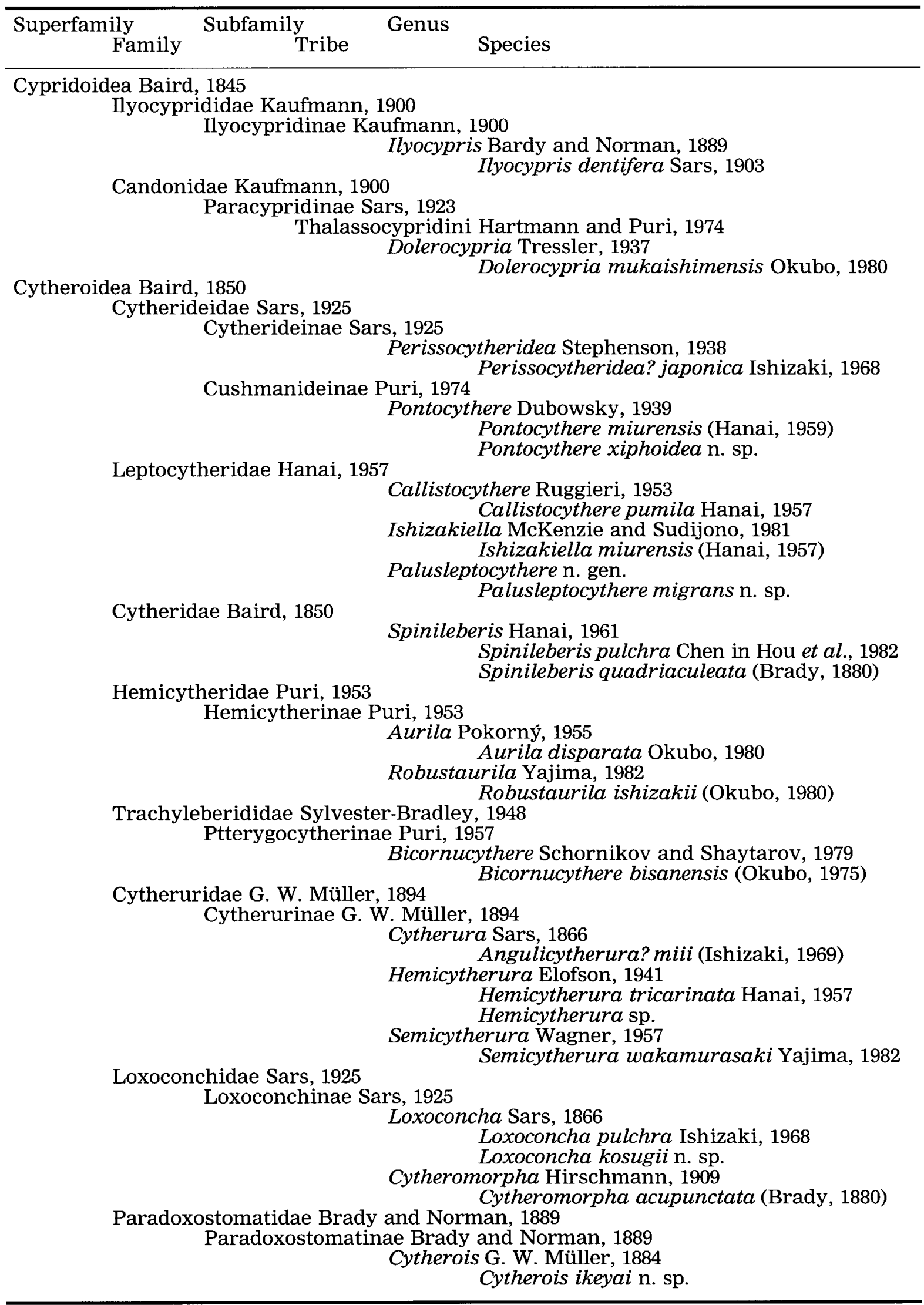


are compiled in Table 5. Classification of 21 ostracod species found in the study area is shown in Table 2.

All illustrated and type specimens are deposited in the collection of the Shizuoka University Museum, identified by numbers with the prefix SUM-CO.

Abbreviations. Av, average; $\mathrm{LV}$, left valve; $\mathrm{N}$, individual number; $\mathrm{OR}$, observed range; $\mathrm{RV}$, right valve; SRDP, salinity range of main distributional points of each species at low tide.

\section{Systematics \\ Ilyocypris dentifera Sars, 1903}

(Fig. 2A-D)

Ilyocypris dentifera Sars, 1903: 38, 39, pl. 4, figs 8, 8a-c; Victor and Fernando 1980, figs $1-38$.

Ilyocypris angulata Sars, 1903: 39, 40, pl. 4, figs 9, 9a; Okubo 1974: 48-50, figs 1, 2;

Ikeya et al. 1985, pl. 1, figs 6, 9. [Synonymized by Victor and Fernando 1980]

Diagnosis. Carapace outline in dorsal view spindle-shaped with two prominent sulci and a few nodes. Carapace surface covered with deep, fine pits. Adductor muscle scars situated in deep fossa. Short small spines on anterior and posterior margins.

Remarks. Soft parts of this species were illustrated as I. angulata by Okubo (1974). This species is generally known as a fresh-water taxon, but in the present survey it occurred in saline water of approximate $21 \%$.

\section{Dolerocypria mukaishimensis Okubo, 1980}

(Figs 2E-J, 3, 4)

Dolerocypria mukaishimensis Okubo, 1980: 20, fig. 2; Hiruta and Smith 2001, fig. 15E. Dolerocypria mukaishimense: Okubo 1991: 124, fig. 2 a.

Diagnosis. Flattened sub-triangular carapace outline in lateral view, without conspicuous differences between male and female. Greatest height a little in front of mid-length (Figs 2E, F, 3A). Ventral margin almost straight with slight concavity in middle. Carapace surface smooth. In male copulatory organ (Fig. 4E), basal capsule semicircular and distal lobe indivisible and sub-trapezoidal. Copulatory duct long and sinuous (forms complex series of loops), with marked distal taper. Two small processes present medially, cigar-like structure at base of distal lobe and shorter structure located mid-ventrally on basal capsule.

Description. Carapace translucent. Transition between dorsal and posteroventral margin very narrowly rounded, almost pointed. Anterior and posterior marginal infoldments wide; line of concrescence smooth and very close to outer margin; marginal pore canals short and straight. Hingement (Fig. 2J): modified adont, i.e., in RV, simple bar bearing small knob interlocking with corresponding socket of LV. Muscle scars: row of four suboval scars, fused scars posterior to this row. Antennule (Fig. 3B): 7 articulated segments; 1st and 2nd segments almost 


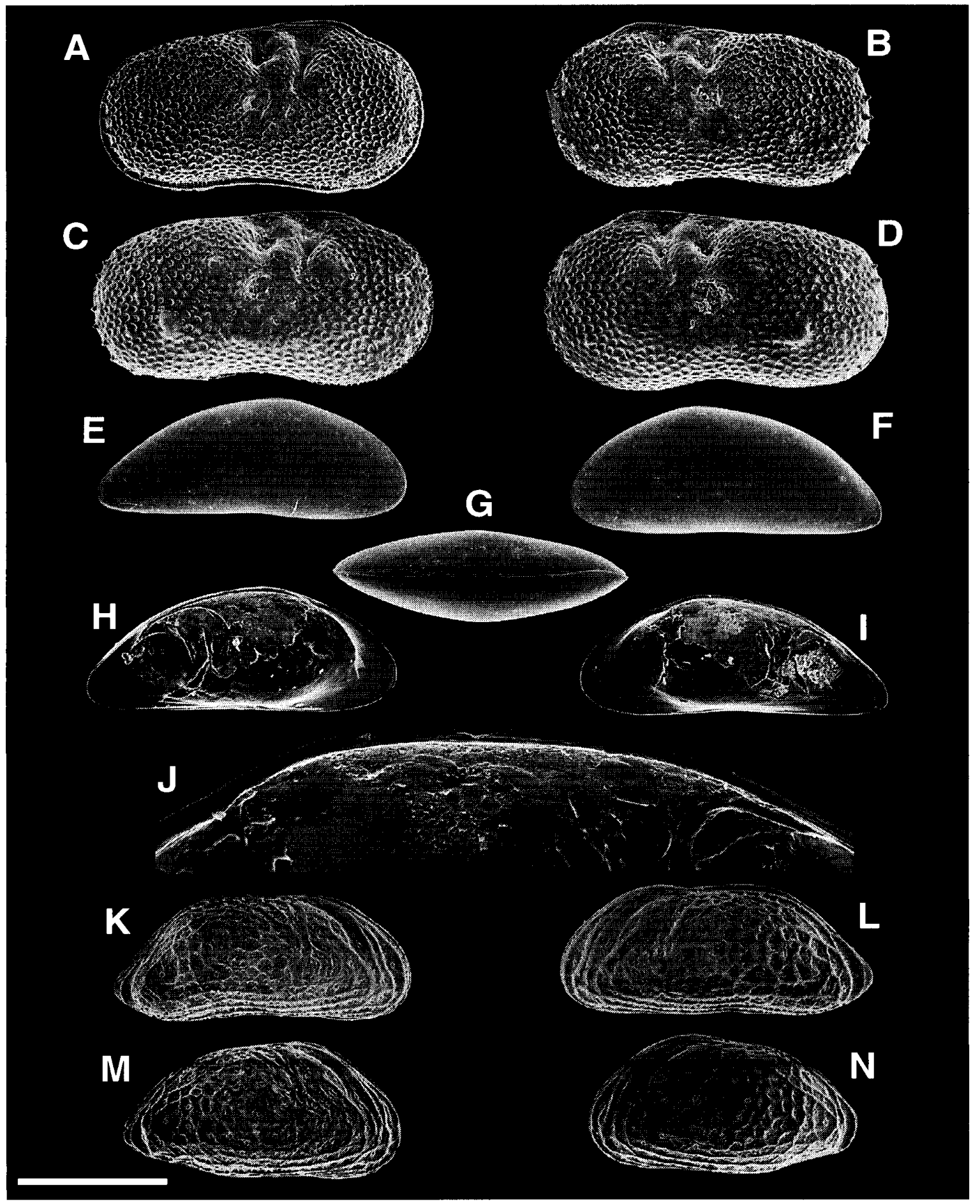

Fig. 2. Ilyocypris dentifera Sars, 1903 (A-D), Dolerocypria mukaishimensis Okubo, 1980. (EJ), and Perissocytheridea? japonica Ishizaki, $1968(\mathrm{~K}-\mathrm{N})$. A, male carapace in external right lateral view (SUM-CO-1101); B, male LV in external view (SUM-CO-1102); C, D, female RV and LV in external lateral view (SUM-CO-1103); E, RV in external lateral view (SUM-CO-1104); F, LV in external lateral view (SUM-CO-1105); G, carapace in external dorsal view (SUM-CO1106); $\mathrm{H}$, male LV in internal lateral view (SUM-CO-1107); I, male RV in internal lateral view (SUM-CO-1108); J, hingement of male RV (SUM-CO-1108); K, male carapace in external 
fused; spatula-like seta present at end of 7th segment. Antenna (Fig. 3C, C', D, D'): 6 articulated segments; 4th and 5th podomeres distinctly divided in male but fused in female; fourth podomere of male with 1 seta bearing trumpet-like structure and another stout, non-trumpet-like seta distally; 4 long, 1 medium, and 1 short swimming setae on 3rd podomere (gap between 4 long setae and medium long seta); 3 large terminal claws in males and 4 in females. Mandible (Fig. 3E, E'): 5 articulated segments; coxa bearing teeth and 2 comb-like seta at anterior end and 1 seta on anterior distal margin; basis (2nd segment) bearing small branchial plate with plumose setae; 2 big setae with ramifications at regular intervals present on posterior margin of 1st segment of endopodite; 3rd segment of endopodite bearing 4 claw-like setae at distal end. Maxillule (Fig. 4A, A'): thin branchial plate with 17-24 setae; basal podomere bearing palp and 3 endites; palp with 9 simple setae, 3 plumose setae, and seta with ramifications at regular intervals; 3 endites bearing several setae. Fifth limb (Fig. 4B, B'): thin branchial plate with spinules; 13 plumose setae at anterior end; 2 plumose setae and 3 setae directed posteriorly with short, fine hairs on ventral margin. Walking legs (Fig. 4C): 5 articulated segments; very long claw-like seta present at distal end of 5th segment. Cleaning limb (Fig. 4D): 4 articulated segments; very long and stout reflexed seta with comb-like distal setules. Furca (Fig. 4G): 1 seta and 2 strong distal claws with distal serration. In female genital lobe, oval capsule containing meandering duct-like structure (Fig. 4F, F').

Remarks. The male copulatory organ (Fig. 4E) is in an non-copulation position. Unknown organs were observed (Fig. 4I, I'). Okubo (1980b) illustrated only a female specimen of Dolerocypria mukaishimensis since male specimens could not be found. This species resembles $D$. taalensis (Tressler, 1937) which was redescribed by Wouters (1987), but the number of terminal claws of the antenna and the male copulatory organ are distinct (there are no processes on the male copulatory organ in $D$. taalensis). The carapace outline is similar to these of Propontocypris species, but the number of segments in the antennule and the shape of the caudal rami (furcae) are distinctive. Some "Propontocypris" species from Japan, which were reported without soft parts, need to be checked concerning on these characters. "Cyprididae n. sp." of Ikeya and Hanai (1982) probably belongs to this species, certainly to the same genus; however, those authors described no details of the soft parts.

\section{Perissocytheridea? japonica Ishizaki, 1968}

(Fig. 2K-N)

Clithrocytheridea sp. A: Ishizaki, 1968: 18, pl. 3, fig. 12.

Perissocytheridea japonica Ishizaki, 1968: 18, pl. 1, fig. 4, pl. 3, figs 4, 5; Hou et al. 1982, pl. 71, figs 19, 20, pl. 73, figs 9-13, text-fig. 25a, b; Okubo 1983: 403-409, figs 1-3; Ikeya et al. 1985, pl. 2, figs 4, 5, 7, 8; Wang, P.X. et al. 1988: 236, pl. 38, figs 7, 8; Ikeya and Itoh 1991, fig. 20D; Yamane 1998, pl. 9, fig. 3.

right lateral view (SUM-CO-1112); L, male carapace in external left lateral view (SUM-CO1113); $\mathrm{M}$, female carapace in right lateral view (SUM-CO-1114); $\mathrm{N}$, female carapace in left lateral view (SUM-CO-1115). Scale bar $=350 \mu \mathrm{m}$ for A-I, $75 \mu \mathrm{m}$ for J. 

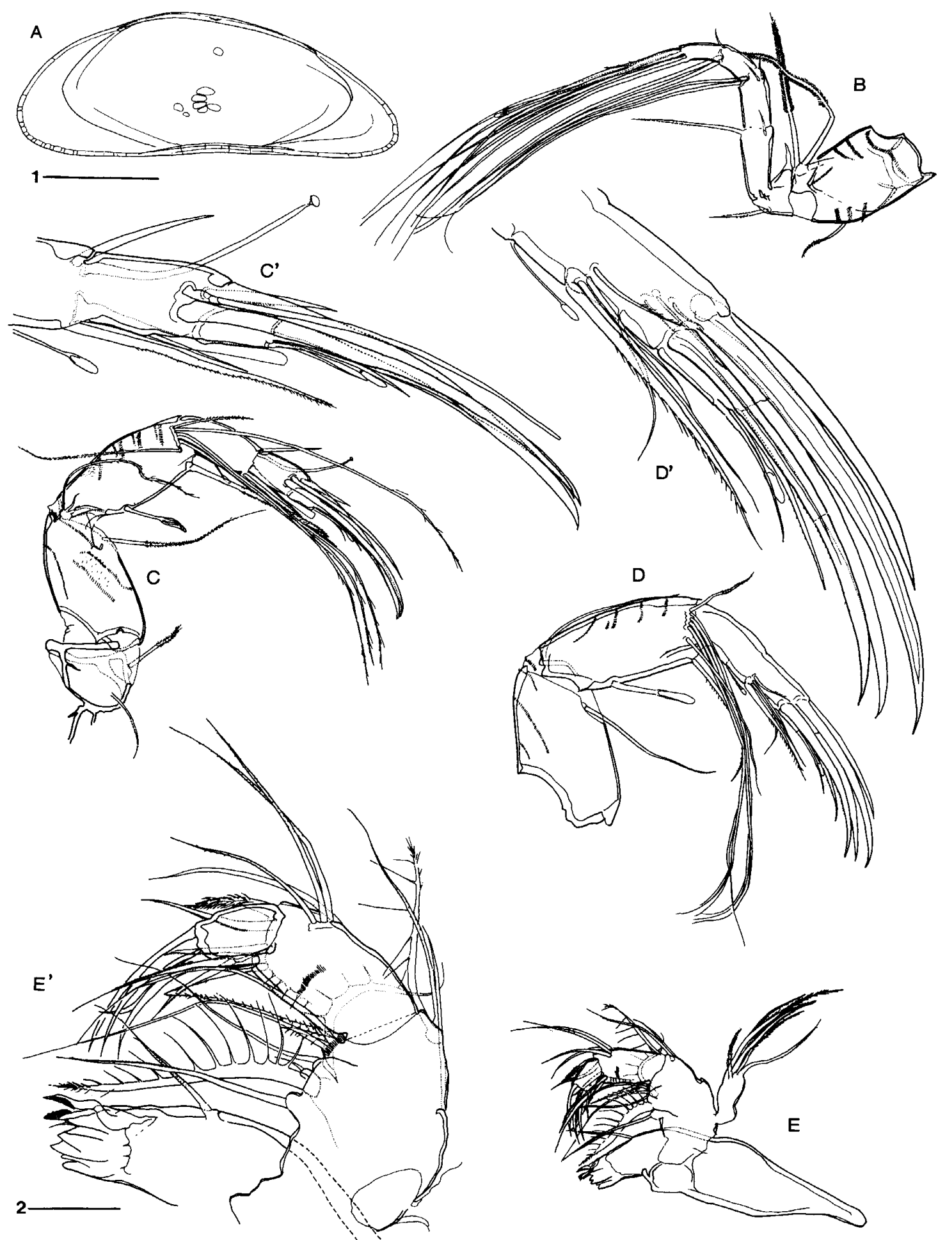

Fig. 3. Dolerocypria mukaishimensis. A, internal view of female RV; B, antennule of male; $\mathrm{C}$, antenna of male; $\mathrm{D}$, antenna of female; E, mandible; C'-E', enlarged details of C-E, respectively. A, SUM-CO-1109 (female); B, C, and E, SUM-CO-1110 (male); D, SUM-CO-1111 (female). Scale bar $1=200 \mu \mathrm{m}$ for A. Scale bar $2=50 \mu \mathrm{m}$ for B-E, $20 \mu \mathrm{m}$ for B'-E'. 


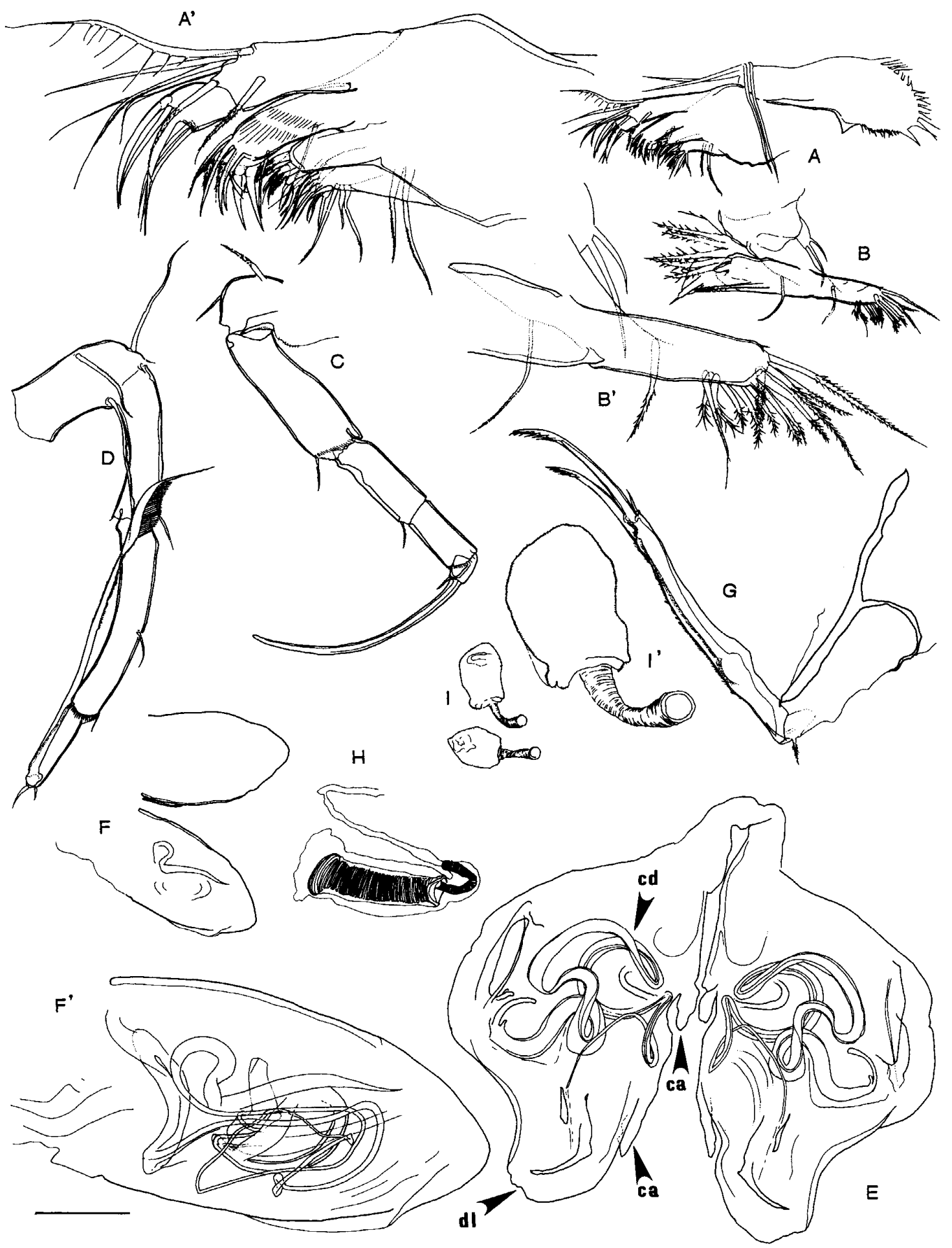

Fig. 4. Dolerocypria mukaishimensis. A, maxillule; B, fifth limb; C, walking leg; D, cleaning limb; E, male copulatory organ; F, female copulatory organ; G, furca; H, Zenker's organ; I, unknown organ; A', B', F', and I', enlarged details of A, B, F, and I, respectively; ca, copulatory apparatus; cd, copulatory duct; dl, distal lobe. A-E and G-I, SUM-CO-1110 (male); F, SUM-CO1111 (female). Scale bar $=50 \mu \mathrm{m}$ for A-D and G-I, $20 \mu \mathrm{m}$ for A', B', and I', $57 \mu \mathrm{m}$ for F, $23 \mu \mathrm{m}$ for $\mathrm{E}$ and $\mathrm{F}$. 
Clithrocytheridea? japonica: Hanai et al. 1977: 24.

Diagnosis. Conspicuous sexual dimorphism in carapace lateral outline, elongate sub-trapezoidal and sub-triangular in male and female, respectively. Caudal process well developed. Carapace surface covered with striking reticulations. A few deep fossae in each reticular unit. Reticular muri parallel to outline in marginal zone.

Remarks. This species contrasts with Perissocytheridea matosoni (Stephenson, 1935), the type species of the genus Perissocytheridea proposed by Stephenson (1938), in carapace outline and ornamentation. Hanai et al. (1977) suggested that this taxon should represent a new genus.

Pontocythere miurensis (Hanai, 1959)

(Fig. 5A-D)

Cushmanidea miurensis Hanai, 1959: 299, pl. 16, figs 7-10, text-fig. 1a, b; 1961a, textfig. $4 \mathrm{~A}(1 \mathrm{a}, \mathrm{b})$.

Pontocythere miurensis: Hanai et al. 1977: 25; Wakamatsu 1988, pl. 34, figs 7-9.

Cushmanidea subjaponica: Okubo 1977: 133-140, figs 2, 3. [nec Hanai, 1959]

Pontocythere subjaponica: Kamiya and Nakagawa 1993, pl. 1, figs 7, 8; Irizuki et al. 1998, fig. 2(1). [nec Hanai, 1959]

Diagnosis. Sub-crescentic carapace outline in lateral view, highest in middle. Female higher and shorter than male. Anterior margin gently tapering off. Moderate caudal process in lower half of posterior margin, relatively larger in right valve. Carapace surface smooth. Some very inconspicuous muri parallel to anterior margin. Narrow and weak fossae in mid-ventral margin of male. In male copulatory organ (not figured), capsule sub-square, distal lobe (=supporting lobe) elongate and curved. Copulatory duct coiling. Two 'claspers'; one stout and J-shaped, extending ventrally with small process in middle, other thin and elongated dorsally.

Remarks. There is considerable confusion in the identification of the species of this genus from Japan because all have similar ornamentation patterns on the

Fig. 5. Pontocythere miurensis (Hanai, 1957) (A-D) and Pontocythere xiphoidea n. sp. (E-Q). A, male carapace in external right lateral view (SUM-CO-1116); B, male carapace in external left lateral view (SUM-CO-1117); C, female carapace in external lateral view (SUM-CO-1118); $\mathrm{D}$, female carapace in external lateral view (SUM-CO-1119); $\mathrm{E}$, male carapace in external right lateral view (holotype, SUM-CO-1120); F, male carapace in external left lateral view (paratype, SUM-CO-1121); G, H, female RV and LV in external lateral view (paratype, SUMCO-1122); I, male carapace in external dorsal view (paratype, SUM-CO-1123); J, female carapace in external dorsal view (paratype, SUM-CO-1124); K, L, male LV and RV in internal lateral view (paratype, SUM-CO-1125); $\mathrm{M}$, female LV in internal lateral view (paratype, SUM-CO1126); N, female RV in internal lateral view (paratype, SUM-CO-1127); O, muscle scars of male RV (paratype, SUM-CO-1125); P, Q, hingement of female RV (paratype, SUM-CO-1127), anterior and posterior hinge areas. Scale bar $=250 \mu \mathrm{m}$ for $\mathrm{A}-\mathrm{C}, 170 \mu \mathrm{m}$ for $\mathrm{E}-\mathrm{N}, 30 \mu \mathrm{m}$ for $\mathrm{O}, 28 \mu \mathrm{m}$ for $\mathrm{P}$ and $\mathrm{Q}$. 


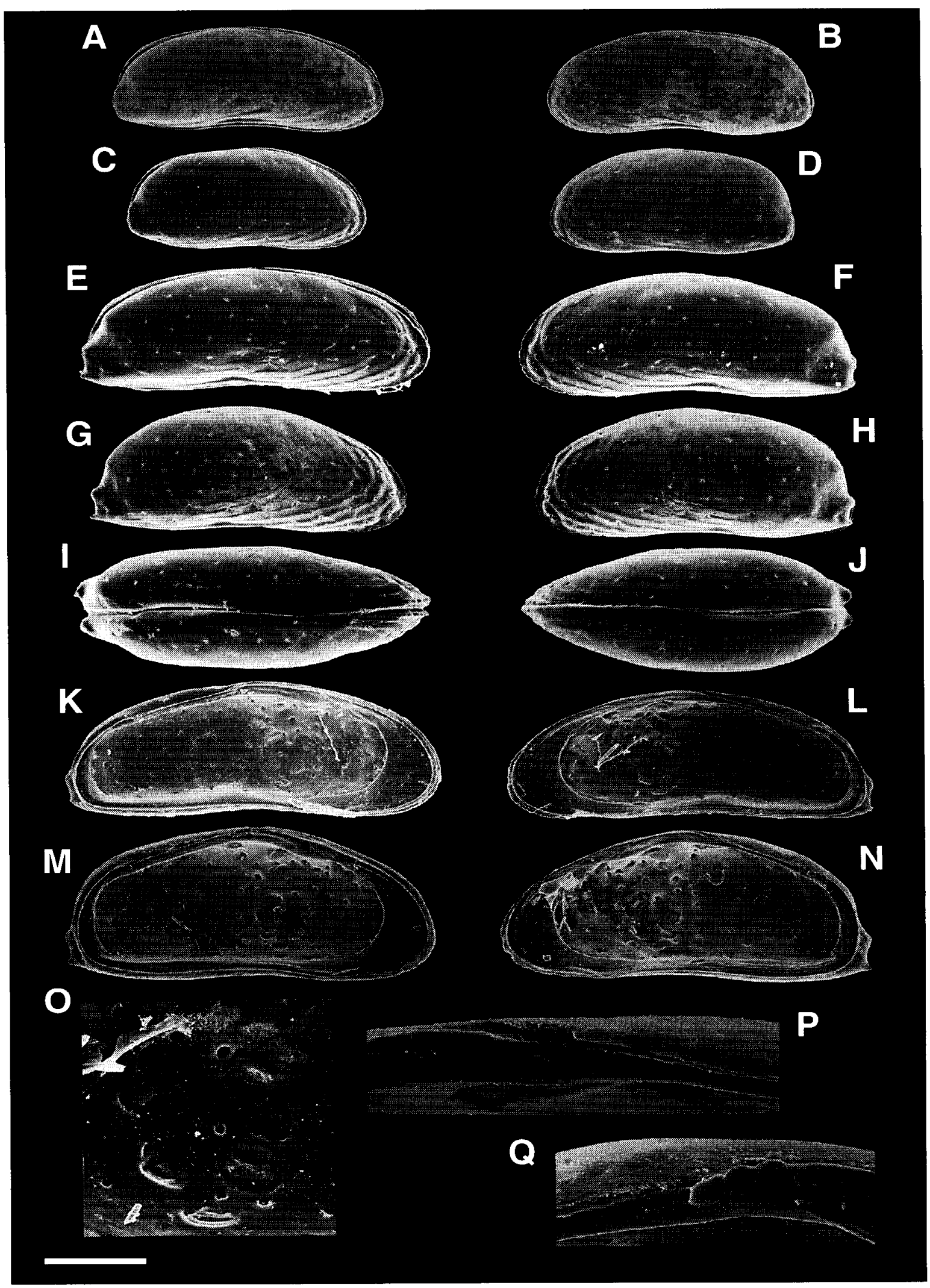


carapace. The authors have examined the holotypes of Pontocythere japonica (Hanai, 1959), P. kashiwarensis (Hanai, 1959), P. miurensis, and P. subjaponica (Hanai, 1959) by SEM. The specimens from the Obitsu River Estuary are smaller than the holotype of $P$. miurensis but the outline and the distributional pattern of pore-systems are identical with those of that species. The photographs and drawings of Okubo (1977), Kamiya and Nakagawa (1993), and Irizuki et al. (1998) are detailed enough to confirm the specimens described in those texts as conspecific with $P$. miurensis; most other listings, however, do not provide sufficient anatomical information to allow us to reach a determination with confidence.

\section{Pontocythere xiphoidea n. sp.}

(Figs $5 \mathrm{E}-\mathrm{Q}, 6$ )

Pontocythere japonica: Yamane 1998, pl. 9, fig. 7. [nec Hanai, 1959]

Types. Holotype, SUM-CO-1120 (complete male carapace, length: $0.546 \mathrm{~mm}$, height: $0.209 \mathrm{~mm}$, width: $0.183 \mathrm{~mm}$ ); paratypes, SUM-CO-1121 (complete male carapace), SUM-CO-1122 (LV and RV of female), SUN-CO-1123 (complete male carapace), SUM-CO-1124 (complete female carapace), SUM-CO-1125 (RV and LV of female), SUM-CO-1126 (LV of female), SUM-CO-1127 (RV of female), SUM-CO-1128 (RV, LV, and soft parts of male), SUM-CO-1129 (RV, LV, and soft parts of female), SUM-CO1130 (RV, LV, and soft parts of male), and SUM-CO-1131 (RV, LV, and soft parts of female).

Etymology. Greek xiphoeides (xiphoid, meaning sword-shaped), referring to the male carapace form.

Type locality. Loc. 6: $1000 \mathrm{~m}$ off beach ridge on sand flat, at mouth of Obitsu River, Kisarazu City, Chiba Prefecture, Japan ( $\left.35^{\circ} 25.7^{\prime} \mathrm{N}, 139^{\circ} 53.4^{\prime} \mathrm{E}\right)$, water depth ca $10 \mathrm{~cm}$ at lowest low tide.

Diagnosis. Carapace subcrescentic in lateral view, highest in middle (Fig. 5E$\mathrm{H})$. Female higher and shorter than male. Anterior margin gently tapering off. Caudal process produced from ventral half of posterior margin, with 1 denticletubercle each at upper and lower corners. Ventral margin concave medially. Carapace surface smooth. Several muri running parallel to anterior and posterior margins, with progressive increase in development anteriorly. Weak fossae also evident mid-ventrally. In male copulatory organ (Fig. 6J), capsule subquadrate, distal lobe (=supporting lobe) triangular. Copulatory duct long and stout; tip bent and swollen, with pointed end bearing long, filiform seta. One clasping apparatus bending and twisting around copulatory duct.

Description. Carapace outline elongate and slim in lateral view. Male carapace longer than that of female; sexual dimorphism of carapace relatively small. Anterior margin slightly irregular. Along antero-ventral margin, several gentle muri developed in parallel. Hingement (Fig. 5P, Q): antimerodont; on RV, 1 elongate tooth in anterior element; groove in median element; 3 or 4 fine teeth in posterior element. Muscle scars (Figs 5O, 6A, B): frontal scar elongate; mandibular scar ovate; upper-most 1 of 4 adductor scars separated from other 3; ventral scar below, between mandibular scar and lower-most adductor scar. Vestibules developed in anterior and posterior parts. Antennule (Fig. 6C): 5 articulated segments; 5th seg- 


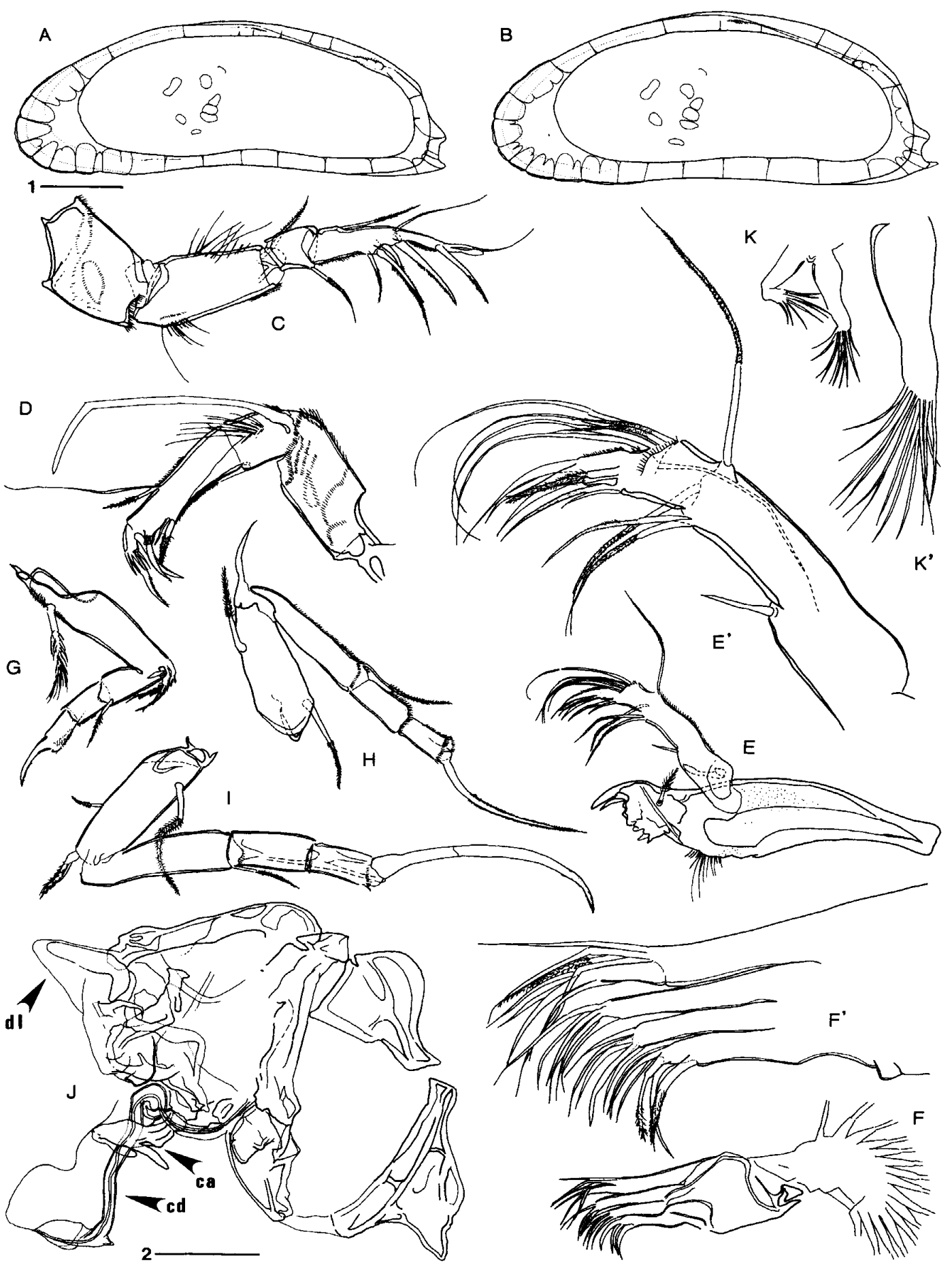

Fig. 6. Pontocythere xiphoidea n. sp. A, internal view of male RV; B, internal view of female RV; C, antennule; D, antenna; E, mandible; F, maxillule; G, first thoracic leg; H, second thoracic leg; I, third thoracic leg; J, copulatory organ of male; $\mathrm{K}$, brush-shaped organ; E', F', and $\mathrm{K}$, enlarged details of $\mathrm{E}, \mathrm{F}$, and $\mathrm{K}$, respectively; ca, clasping apparatus; cd, copulatory duct; dl, distal lobe. A, SUM-CO-1128 (paratype, male); B, SUM-CO-1129 (paratype, female); C-J, L-R, SUM-CO-1130 (paratype, male); K, SUM-CO-1131 (paratype, male). Scale bar $1=100 \mu \mathrm{m}$ for A and B. Scale bar $2=50 \mu \mathrm{m}$ for $\mathrm{C}-\mathrm{K}, 20 \mu \mathrm{m}$ for E', F', and $\mathrm{K}^{\prime}$. 
ment bearing 1 straight, 1 spatula-like, and 1 claw-like setae. Antenna (Fig. 6D): 4 articulated segments; 3rd segment bearing 2 stout and 1 thin setae at distal end; 4 th segment bearing 1 stout, claw-like seta and 5 short setae at distal end. Mandible (Fig. 6E, E'): 5 articulated segments; coxa (basal segment) bearing well developed teeth at anterior end and 1 plumose seta on anterior distal margin; basis (2nd segment) bearing exopodite reduced to simple short seta, and 1 simple short seta at distal-ventral end; 2nd and 3rd segments of endopodite almost fused; 1st segment of endopodite bearing 4 long setae; 2nd segment bearing 5 long setae on ledge and 2 medium-long and short setae at distal end; 3rd (distal) segment bearing 3 simple setae and 1 plumose seta at distal end. Maxillule (Fig. 6F, F'): thin branchial plate with 15-16 plumose setae; basal podomere bearing 1 palp and 3 endites; palp with 8 setae, 3 endites bearing 6, 5, and 6 setae, respectively. Thoracic legs (Fig. 6G-I): all 3 legs 4-segmented; 1st thoracic leg smallest, terminating in short claw with short, fine hairs on distal half of anterior margin; 2nd leg medium-long and bearing long and thin claw-like setae with setules; 3rd leg largest and bearing long and stout claw-like seta with short, fine hairs.

Remarks. This species is similar to $P$. subjaponica, but the carapace outline in the male is slimmer than that of $P$. subjaponica. A distinctive difference from $P$. subjaponica is observed in the pore distributional pattern. Five additional pores compared with $P$. subjaponica are observed clearly in the posterior half of the carapace. This species tends to appear further offshore than $P$. miurensis.

\section{Callistocythere pumila Hanai, 1957}

(Fig. 7A, B)

Callistocythere pumila Hanai, 1957a: 459, 460, pl. 10, fig. 2a-c; Okubo 1975, fig. 1; Yamane 1998, pl. 3, fig. 5; Tsukagoshi 1998, pls 1-4, text-figs 1, 2; Irizuki and Hosoyama 2000, fig. 3(3).

Callistocythere laevis Okubo, 1979, pl. 2, figs e-h, text-fig. 5. [Synonymized by Tsukagoshi 1998]

Diagnosis. Conspicuous sexual dimorphism in carapace ornamentation: female with numerous deep fossae on whole carapace except for noticeable flat tubercle in antero-dorsal area, irregular undulating ridges in posterior half, and 2 strong, parallel, marginal ridges anteriorly; male with weakly developed ornamentation in median area, 2 strong marginal ridges and a few fossae anteriorly, and numerous fossae and a few marginal ridges posteriorly. In male copulatory organ, copulatory duct coiling several times, glans located centrally within coil. Two large, curved claspers present, outer one larger. Thin, subtriangular, supporting lobe occurring distally.

Remarks. The carapace morphology of this species occupies an intermediate position between two genera of Leptocythere and Callistocythere; the male and female forms correspond to the former and the latter, respectively. Because of the large differences between sexes, the female and male individuals were separately described as different species by Okubo (1975 and 1979, respectively); thus, Callistocythere laevis Okubo, 1979 is a junior synonym of $C$. pumila. The number and size of the fossae on the carapace vary in the male. 


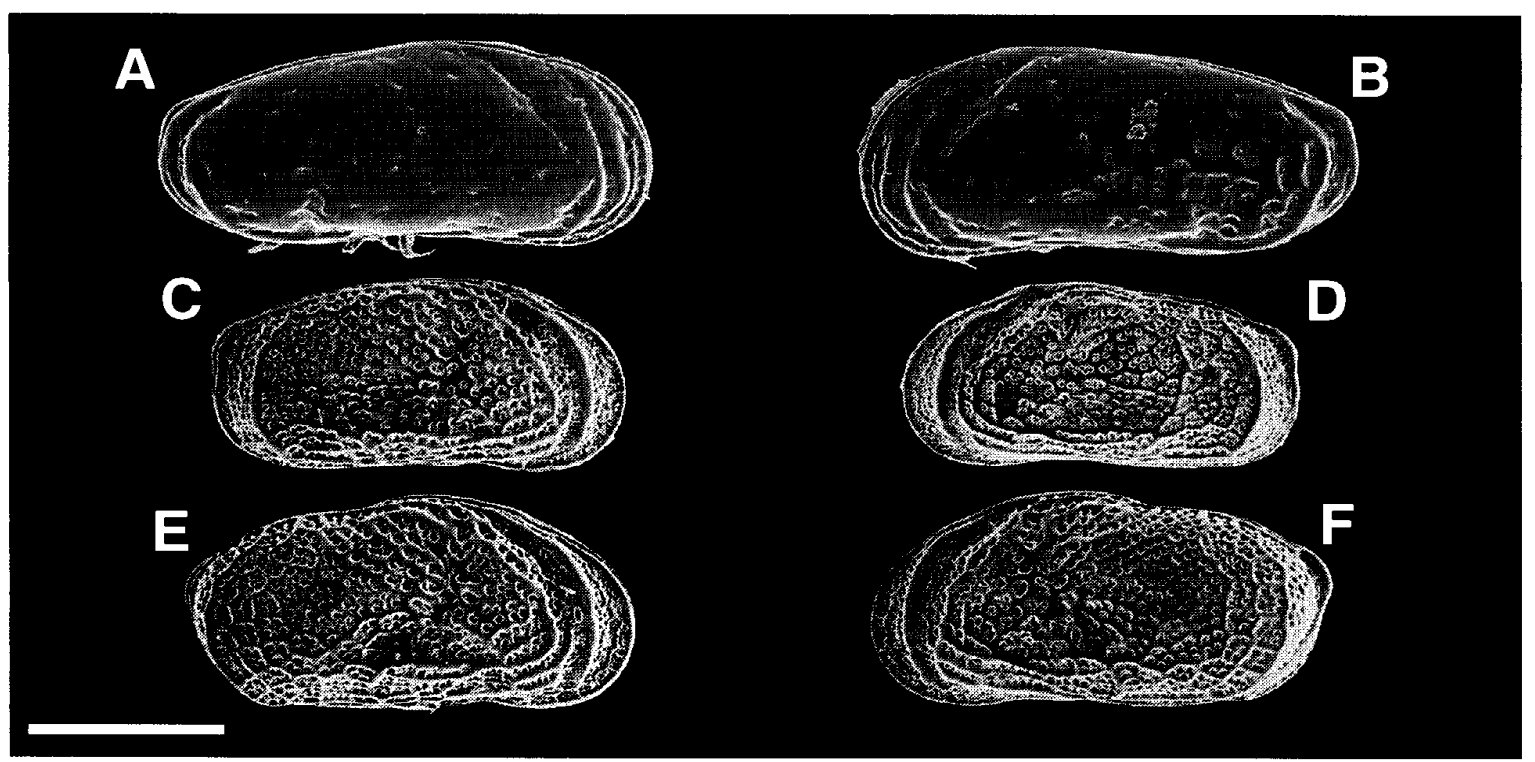

Fig. 7. Callistocythere pumila Hanai, 1957 (A, B) and Ishizakiella miurensis (Hanai, 1957) (CF). A, male carapace in external right lateral view (SUM-CO-1132); B, male carapace in external left lateral view (SUM-CO-1133); C, male carapace in external right lateral view (SUM-CO1134); D, male carapace in external left lateral view (SUM-CO-1135); E, female carapace in external right lateral view (SUM-CO-1136); F, female carapace in external left lateral view (SUM-CO-1137). Scale bar $=200 \mu \mathrm{m}$ for A and B, $300 \mu \mathrm{m}$ for C-F.

\section{Ishizakiella miurensis (Hanai, 1957)}

(Fig. 7C-F)

Tanella miurensis Hanai, 1957a: 462, 463, pl. 9, fig. 1a-e, text-fig. 2I, J.

Tanella pacifica Hanai, 1957a: 465 (new name for Cythere inflata Brady, 1890 preoc-

cupied); 1961a, text-fig. 10 (5); Hanai et al. 1977: 34; Frydl 1982, listed in table 1. Ishizakiella pacifica: Tsukagoshi 1992: 5, figs a-g.

Ishizakiella miurensis: Tsukagoshi 1994: 303, figs 3, 7B, 8A-I, 9, 12B; Tsukagoshi and

Kamiya 1996, fig. 17A-D; Yamaguchi 2000, figs 2A, B, 8C, D.

Diagnosis. Carapace covered with coarse reticulations and strong, sub-peripheral ridges anteriorly and posteriorly. Male copulatory organ bearing 2 rounded and pointed claspers. Additionally, male copulatory organ with striking serrature on middle of copulatory duct.

Remarks. Species of the genus Ishizakiella in Japan were described in detail by Tsukagoshi (1994). Yamaguchi (2000) examined mtDNA to determine the relationships among populations of these species and presumed their course of migration. For the transition of the scientific name of this species, see Tsukagoshi (1994).

\section{Genus Palusleptocythere n. gen.}

Type species. Palusleptocythere migrans n. sp. in this paper.

Etymology. Latin palus $=$ marsh. 
Diagnosis. Carapace thin and smooth medially and especially dorsally. In lateral outline, bean-like in shape. Length/height ratio low. Duplicature making narrow vestibule. Marginal pore canals simple and straight, in contrast to more complex, branched forms found in other leptocytherid species. Weak hingement similar to that of juveniles of Leptocythere species.

Remarks. The carapace morphology is different from that of other leptocytherid adults, but similar to that of juveniles of other leptocytherid genera. The soft parts, however, show the characteristic adult features of this family. Dr. David J. Horne (pers. comm.) pointed out that this genus has "juvenile" carapace features, but that the appendages are typical of adult Leptocythere and/or Callistocythere and that the genus Cluthia is an example of a leptocytherid genus with juvenile features in both valves and appendages. In Japan and adjacent areas, three extant leptocytherid genera occur, viz, Callistocythere, Leptocythere, and Ishizakiella. We have been unable to determine the phylogenetic relationships between those taxa and the new genus. Although a few species of Leptocythere without branching (polyfurcate) marginal pore canals are known from freshwater environments in Europe (e.g., Petkovski and Keyser 1992), the new species described below can be easily discriminated from members of this genus (the type species of which is Leptocythere pellucida (Baird, 1850) with the elongate carapace and well developed teeth of hingement). In the authors' opinion, these differences warrant the proposal of a new genus.

\section{Palusleptocythere migrans n. sp.}

(Figs 8, 9)

Types. Holotype, SUM-CO-1138 (complete male carapace, length: $0.401 \mathrm{~mm}$, height: $0.240 \mathrm{~mm}$, width: $0.157 \mathrm{~mm}$ ); paratypes, SUM-CO-1139 (complete male carapace), SUM-CO-1140 (complete female carapace), SUM-CO-1142 (complete female carapace), SUM-CO-1142 (complete male carapace), SUM-CO-1143 (complete female carapace), SUM-CO-1144 (RV and LV of male), SUM-CO-1145 (RV and LV of male), SUM-CO-1146 (RV and LV of female), SUM-CO-1147 (soft parts of male).

Etymology. Latin migrans (migrant), alluding to change of its habitat in the field area studied.

Type locality. Loc. B: small creek with associated flora of halophilous grass, at mouth of Obitsu River, Kisarazu-City, Chiba Prefecture, Japan $\left(35^{\circ} 24.6^{\prime} \mathrm{N}\right.$, $139^{\circ} 54.2^{\prime} \mathrm{E}$ ), muddy sand bottom, water depth $\mathrm{ca} 5 \mathrm{~cm}$ at lowest low tide.

Diagnosis. In lateral view, highest point of carapace at two-fifths from anterior end (Fig. 8A-D). Carapace surface weakly ornamented except for scattered fine pits and muri at or near anterior, ventral, and posterior margins. In male copulatory organ (Fig. 9J), distal lobe forming right triangle. Two clasping apparatuses present, one straight and narrowing distally, other one cigar-like with irregular inner margin. Copulatory duct coiling a few times, and glans narrowing at outside of coil.

Description. Sexual dimorphism present but not pronounced, female longer and higher than male. Hingement (Fig. 8I-L): modified amphidont; in RV, anterior element bearing 2 to 3 teeth, median element forming smooth bar, posterior element with 5 teeth; these teeth interlocking with corresponding sockets of LV; snap 


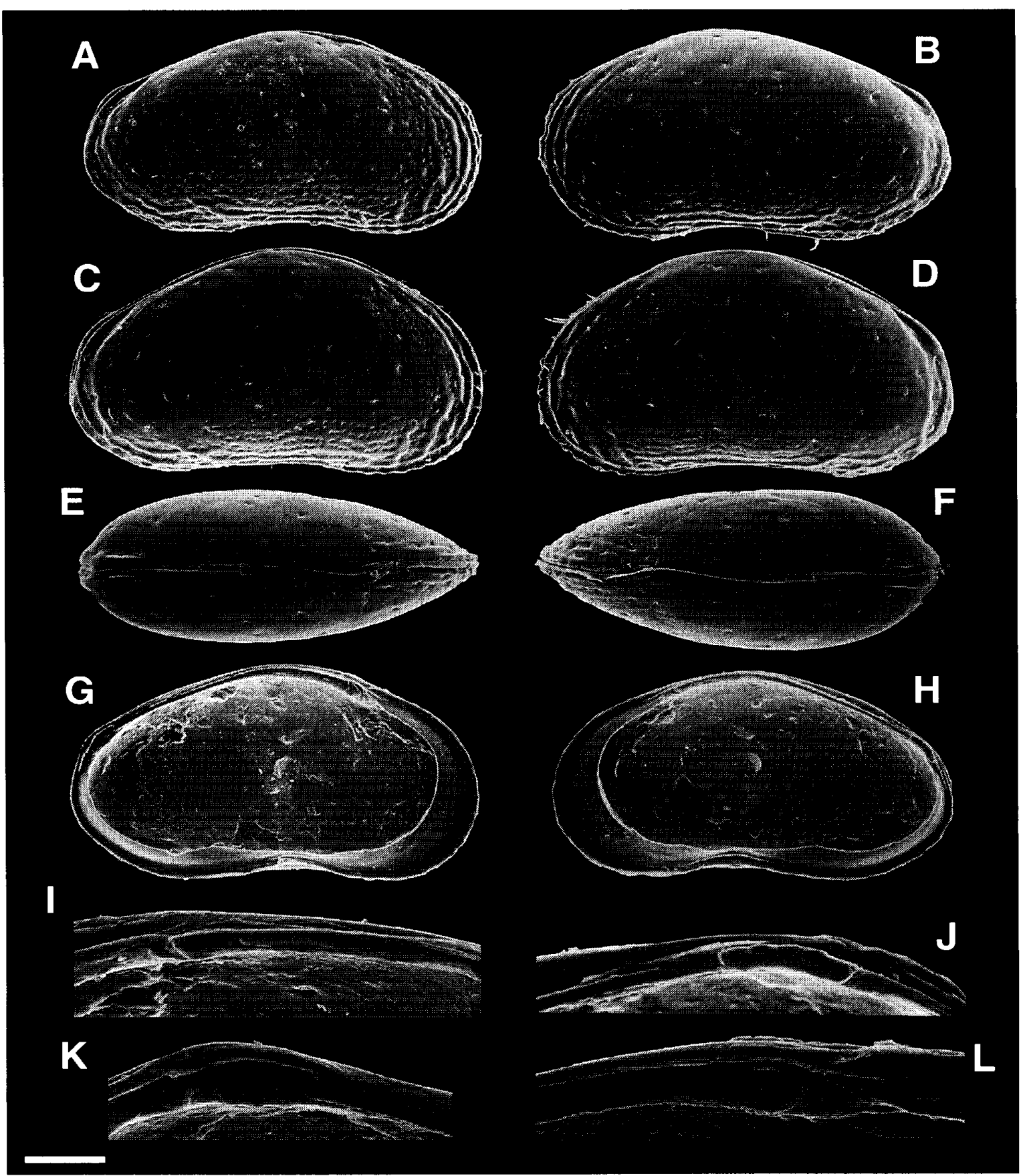

Fig. 8. Palusleptocythere migrans n. sp. A, male carapace in external right lateral view (holotype, SUM-CO-1138); B, male carapace in external left lateral view (paratype, SUM-CO1139); C, female carapace in external right lateral view (paratype, SUM-CO-1140); D, female carapace in external left lateral view (paratype, SUM-CO-1141); E, male carapace in external dorsal view (paratype, SUM-CO-1142); F, male carapace in external dorsal view (paratype, SUM-CO-1143); G, H, male LV and RV in internal lateral view (paratype, SUM-CO-1144); I, J, anterior and posterior elements of hingement on male RV (paratype, SUM-CO-1144); K, L, posterior and anterior elements of hingement on male LV (paratype, SUM-CO-1144). Scale bar $=100 \mu \mathrm{m}$ for $\mathrm{A}-\mathrm{H}, 20 \mu \mathrm{m}$ for $\mathrm{I}-\mathrm{L}$. 

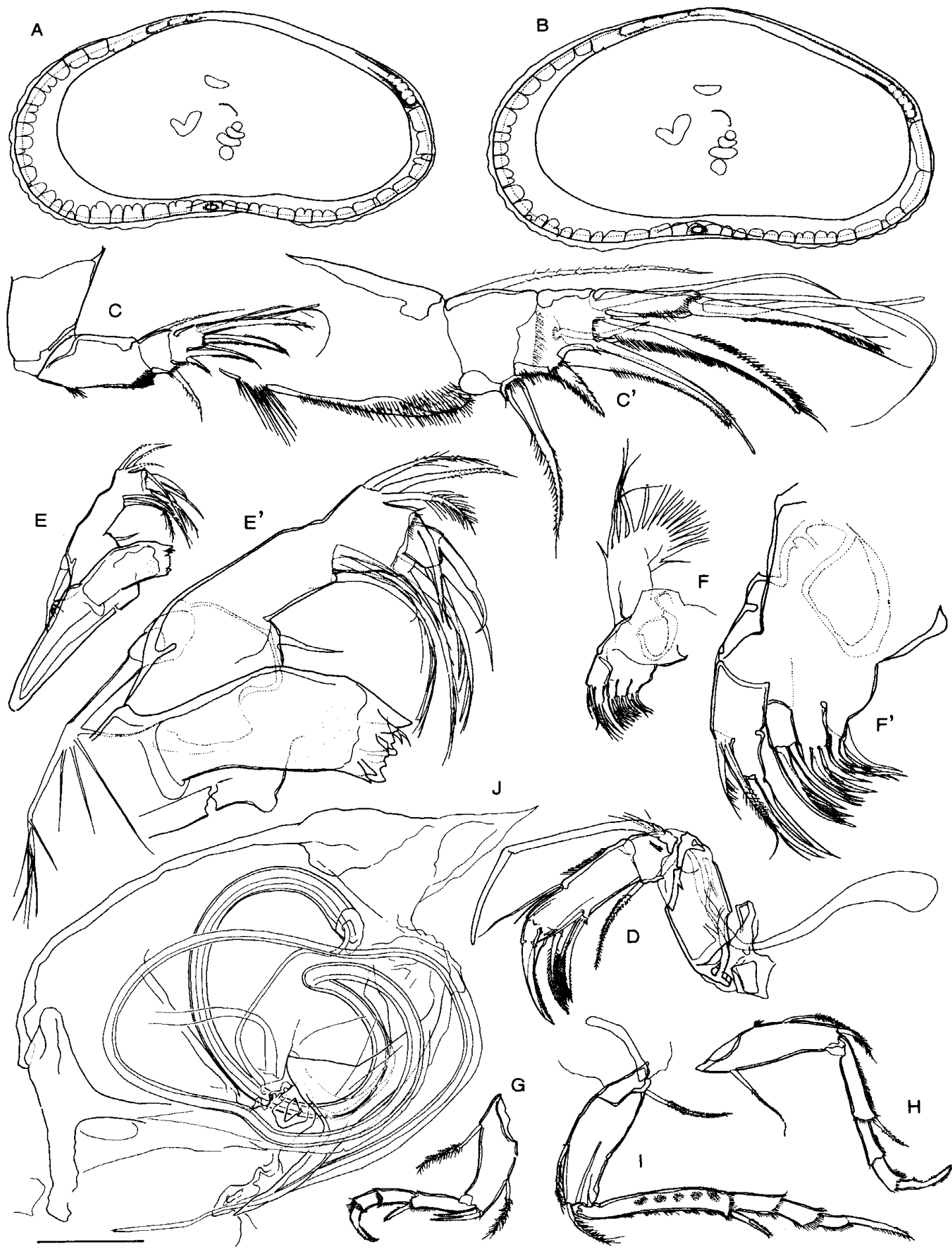

\section{。}
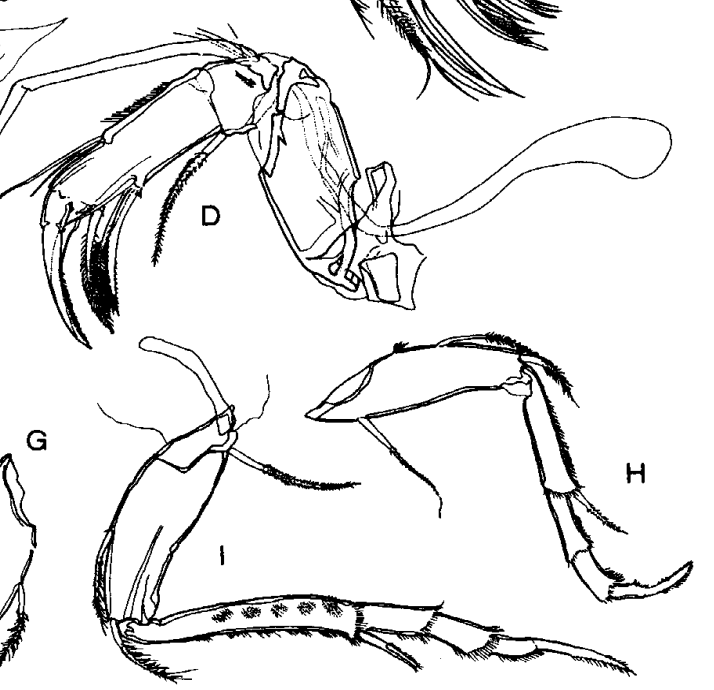

Fig. 9. Palusleptocythere migrans n. sp. A, internal view of male RV; B, internal view of female RV; C, antennule; D, antenna; E, mandible; F, maxillule; G, first thoracic leg; $\mathrm{H}$, second thoracic leg; I, third thoracic leg; J, male copulatory organ; C', E', and F', enlarged details of C, E, and F, respectively. A, SUM-CO-1145 (paratype, male); B, SUM-CO-1146 (paratype, female); C-J, SUM-CO-1147 (paratype, male). Scale bar $=100 \mu \mathrm{m}$ for A and B, $50 \mu \mathrm{m}$ for $\mathrm{C}-\mathrm{H}$, $20 \mu \mathrm{m}$ for C', E', and F', $25 \mu \mathrm{m}$ for $\mathrm{J}$. 
structure present in middle ventral region inside carapace, mid-ventral snap of RV interlocking with corresponding socket of LV. Muscle scars (Fig. 9A, B): row of 4 adductor scars nearly vertical at inside of median to ventro-median of carapace; uppermost and lowermost scars oval, whereas middle 2 scars narrow with hollows in middle; J-shaped frontal scar present in front of upper 2 adductor scars; mandibular scar unclear. Antennule (Fig. 9C, C'): 5 articulated segments; distal end of 5th segment bearing seta, bristle, and claw-like seta with short and long setules. Antenna (Fig. 9D): 4 articulated segments; distal end of 3rd segment bearing feathery seta and claw-like seta with short, fine hairs on distal half of anterior margin; distal end of 4th segment bearing claw-like seta with short, fine hairs on distal half of anterior margin. Mandible (Fig. 9E, E'): 5 segments; coxa bearing teeth at anterior end and 2 short setae on anterior distal margin; distal-ventral end of basis bearing short seta and exopodite as 1 branched seta; distal end of 1st endopodal segment bearing 2 short setae and 2 long setae with long hairs at their distal ends; 2nd endopodal segment bearing 3 plumose setae, 1 stout seta, 1 short seta with short hairs at its root, and 1 long, stout seta with long hairs; 5th segment bearing 2 stout setae and 1 claw-like seta with stout root. Maxillule (Fig. 9F, F'): thin branchial plate with 16 setae; basal podomere bearing 1 palp and 3 endites; palp with 2 plumose setae, 3 simple setae, and 1 seta with 1 branch; 3 endites bearing several setae. Thoracic legs (Fig. 9G-I): all 3 legs 4-segmented; all legs terminating in claw-like setae with serrated fine hairs along distal and proximal parts of anterior margin.

Remarks. At present time, the new genus Palusleptocythere consists of only this species. But estuarine investigations of ostracods in Japan and adjacent areas have just begun. The occurrence of closely related species is expected in the future.

Spinileberis pulchra Chen in Hou et al., 1982

(Figs 10, 11A-D)

Spinileberis pulchra Chen in Hou et al., 1982: 239-240, pl. 86, figs 20-22; Ikeya et al. 1995, figs 7Sp, 8Sp; Wang, Hong and Zhao 1985, pl. 30, fig. 18; Wang, P.-X. et al. 1988: 235, pl. 38, fig. 4; Tanaka et al. 1998, pl. 1, fig. 1.

Diagnosis. Carapace outline and longitudinal ridges as in S. quadriaculeata (Brady, 1880) (Fig. 11A-D). Ornamental reticulation lacking in vicinity of sulci, in space between central and bottom ridges, and in anterior and posterior areas. No spines on posterior ends of central and bottom ridges. Long and fine coil-shaped structure in center of capsule of male copulatory organ (Fig. 10J). Tip of distal lobe pointed ventrally. Copulatory duct short and coiling once.

Description. Antennule (Fig. 10C): 5 articulated segments; 5 th segment bearing 2 long, supple setae and 1 claw-like seta with serrations arranged in 2 rows along its anterior margin. Antenna (Fig. 10D): 4 articulated segments; 4 th segment bearing 2 claw-like setae at posterior middle margin and 1 claw-like seta at distal end; distal seta with row of serrations. Mandible (Fig. 10E, E'): 4 segments; coxa (basal segment) bearing teeth along anterior margin and short plumose seta on anterior margin; basis (2nd segment) bearing exopodite reduced to feathery seta, 1 long seta with short, fine hairs, and small branchial plate on ventral margin; seg- 


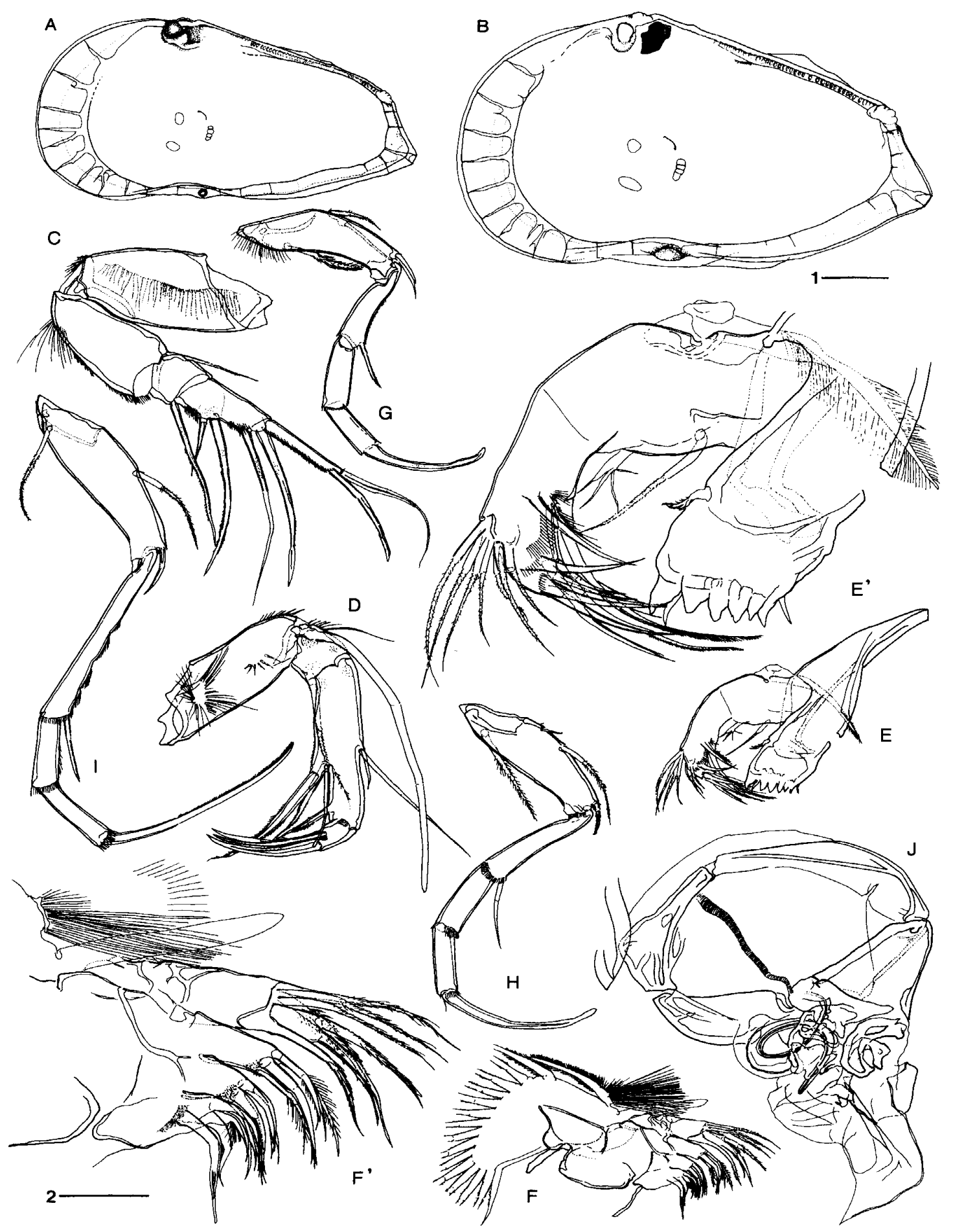

Fig. 10. Spinileberis pulchra Chen, 1982. A, internal view of male RV; B, internal view of female RV; C, antennule; D, antenna; E, mandible; F, maxillule; G, first thoracic leg; H, second thoracic leg; I, third thoracic leg; J, male copulatory organ; $\mathrm{E}^{\prime}$ and $\mathrm{F}^{\prime}$, enlarged details of $\mathrm{E}$ and F, respectively. A, SUM-CO-1151 (male); B, SUM-CO-1152 (female); C-J, SUM-CO-1153 (male). Scale bar $1=100 \mu \mathrm{m}$ for A and B. Scale bar $2=50 \mu \mathrm{m}$ for C-J, $20 \mu \mathrm{m}$ for E' and F'. 
ments of endopodite almost fused; 7 plumose setae on anterior middle margin of endopodite; 2 long distal setae, each with row of short hairs, short seta with row of serrations, and short seta with long hairs present on posterior middle margin of endopodite; 7 stout setae and 3 setae distally on endopodite. Maxillule (Fig. 10F, F'): thin branchial plate with 16 plumose setae, 1 blunt seta, and bundle of long hairs; basal podomere bearing palp and 3 endites, palp with 8 setae, endites each bearing several plumose and simple setae. Thoracic legs (Fig. 10G-I): all 3 legs 4-segmented and similar in shape; long seta at distal end of third legs bearing row of short hairs along distal half of anterior margin.

Remarks. This species was proposed as new in Hou et al. (1982) but the author of the new species was specified therein as T.-C. Chen. The chitinous appendages of this species are illustrated in this paper for the first time. They are very similar to those of $S$. quadriaculeata except for the coil-shaped structure within the male copulatory organ and the length of the copulatory duct.

\section{Spinileberis quadriaculeata (Brady, 1880)}

(Fig. 11E, F)

Cythere quadriaculeata Brady, 1880: 86, 87, pl. 25, fig. 4a-d.

Spinileberis quadriaculeata: Hanai 1961b: 167-170, figs 1-7; Ishizaki 1968: 42, pl. 7, figs 15, 16; 1969: 222, pl. 26, fig. 18; 1971: 95-96, pl. 4, fig. 4; Ishizaki and Kato 1976: 140-141, text-fig. 9, pl. 4, figs 10, 11; Okubo 1978: 94-96, figs 1g-h, 3, 4i-n; Ikeya 1982, fig. 1865; Hou et al. 1982: 238-239, pl. 86, fig. 19; Ikeya 1983, fig. 1 (4-6); Ishizaki 1984, pl. 1 (12); Ikeya et al. 1985, pl. 3, figs 9, 10; Nohara and Tabuki 1985, pl. 2, fig. 13; Wang and Zhang 1987: 291, pl. 2, fig. 32a, b; Ikeya et al. 1987, pl. (2), fig. 8; Bodergat and Ikeya 1988: 421, text-fig. 4f; Ishizaki 1990, fig. 1 (2); Lee 1990: 214-215, pl. 12, fig. 9; Takayasu et al. 1990, fig. 5; Yajima and Lord 1990, fig. 5 (7); Ikeya and Itoh 1991: 145, fig. 24B; Huh 1992, pl. 1, figs 9, 10; Huh and Paik 1992, pl. 3, fig. 8; Ikeya 1993, fig. 3 (2A-E); Ikeya and Shiozaki 1993: 17, fig. 2 (3A-E); Kamiya and Nakagawa 1993, pl. 3, figs 2, 3; Tsukagoshi et al. 1994: 47-48, pl. 2/23, figs 1-6; Ikeya 1995: 31, fig. 3; Ikeya et al. 1995, figs 7Sq, 8Sq; Irizuki et al. 1998, fig. 2 (8); Tanaka et al. 1998, pl. 1, fig. 7; Yamane 1998, pl. 12, fig. 2; Irizuki et al. 1999, fig. 1 (B-1); Irizuki and Hosoyama 2000, fig. 3 (7).

Diagnosis. Carapace irregularly trapezoidal in lateral view. Hingeline almost straight. Dorsal margin of RV slightly arched and overlying left valve in right lateral view. Posterior margin triangular. Ventral margin concave in inner lateral view. Carapace surface ornamented with longitudinal ridges and reticulations. Dorsal ridge running along dorsal margin to upper half of anterior margin. Medial ridge running obliquely across center and terminating posteriorly in sharp spine. Bottom ridge running along ventral margin and forming sharp spine at posterior end. Reticulation developed except for anterior marginal area. Sulci in post-ocular and dorsomedian positions. "Snap structure" in center of inner ventral margin.

Remarks. The ecological relationships between three species of Spinileberis, S. furuyaensis Ishizaki and Kato, 1976, S. pulchra, and S. quadriaculeata, were investigated by Ikeya et al. (1995). In terms of habitat, the present species and $S$. pulchra inhabit the outermost and innermost zones, respectively, relative to the 
shore.

Aurila disparata Okubo, 1980

(Fig. 11G, H)

Aurila disparata Okubo, 1980c: 402-403, figs 4, 7e, f, 9e-j; 1988, text-fig. 3 (part); Yamane 1998, pl. 2, fig. 1.

Diagnosis. Carapace surface covered with reticular fossae (these increasing in size towards carapace margins) and fine pits. Two radial ridges running anteriorly and 1 radial ridge running downwards posteriorly. Narrow dorsal ridge (swollen posteriorly) connecting to eye tubercle.

Remarks. Okubo (1980c) distinguished this species from other species of $\mathrm{Au}$ rila by the shape of the male copulatory organ. This species usually lives on algae on rocky shores. In the study area only one dead (presumably allochthonous) specimen was found, at Loc. 18.

Robustaurila ishizakii (Okubo, 1980)

(Fig. 11I, J)

Mutilus sp.: Hanai 1961a: 372-373, text-fig. 13-1a, b; Hiruta 1981: 17-18, fig. 8(4).

Mutilus assimilus [sic]: Ishizaki 1971: 83, pl. 3, fig. 14; Hou et al. 1982: 178, pl. 75, figs 18-22; Zheng 1987: 197, pl. 4, figs 16-18. [nec Kajiyama, 1913]

Mutilus ishizakii Okubo, 1980c: 405-408, figs 6a-i, 7c, 7d, 11e-g.

Robustaurila assimilis: Yajima 1982: 212, pl. 13, figs 6-8. [nec Kajiyama, 1913]

Mutilus assimilis: Ikeya 1982, fig. 1868a, b; Ikeya et al. 1985, pl. 4, figs 16, 17; Ishizaki and Matoba 1985, pl. 5, fig. 5; Wang, P.X. et al. 1988: 253, pl. 47, figs 5, 6. [nec Kajiyama, 1913]

Aurila sp.: Paik and Lee 1988: 550, pl. 2, fig. 6.

Robustaurila ishizakii: Ikeya and Hamada 1990: 137-144, pl. 17 (138), figs 1-3, pl. 17 (140), figs 1-3, pl. 17 (142), figs 1-4, pl. 17 (140), figs 1-3, text-fig. 1a, b; Ikeya and Itoh 1991: 142, fig. 21C; Tsukagoshi et al. 1994: 49, pl. 2/25, figs 1-6.

Diagnosis. Carapace antero-dorsally arched, coarsely and irregularly reticulate with somewhat prominent radial ridges. Radial ridge to postero-dorsal corner highly sinuous, U-shaped. Postero-dorsal marginal spine absent. Postero-ventral

Fig. 11. Spinileberis pulchra Chen, 1982 (A-D), S. quadriaculeata (Brady, 1880) (E, F), Aurila dispatara Okubo, 1980 (G, H), Robustaurila ishizakii (Okubo, 1980) (I, J), and Bicornucythere bisanensis (Okubo, 1975) (K-N). A, male carapace in external right lateral view (SUM-CO1148); B, male carapace in external left lateral view (SUM-CO-1149); C, D, female RV and LV in external lateral view (SUM-CO-1150); E, F, female RV and LV in external lateral view (SUMCO-1154); G, H, RV and LV in external lateral view (SUM-CO-1155); I, J, RV and LV in external lateral view (SUM-CO-1156); K, L, male RV and LV in external view (SUM-CO-1157); M, N, female RV and LV in external view (SUM-CO-1158). Scale bar $=300 \mu \mathrm{m}$ for A-D and G-N, $200 \mu \mathrm{m}$ for $\mathrm{E}$ and $\mathrm{F}$. 


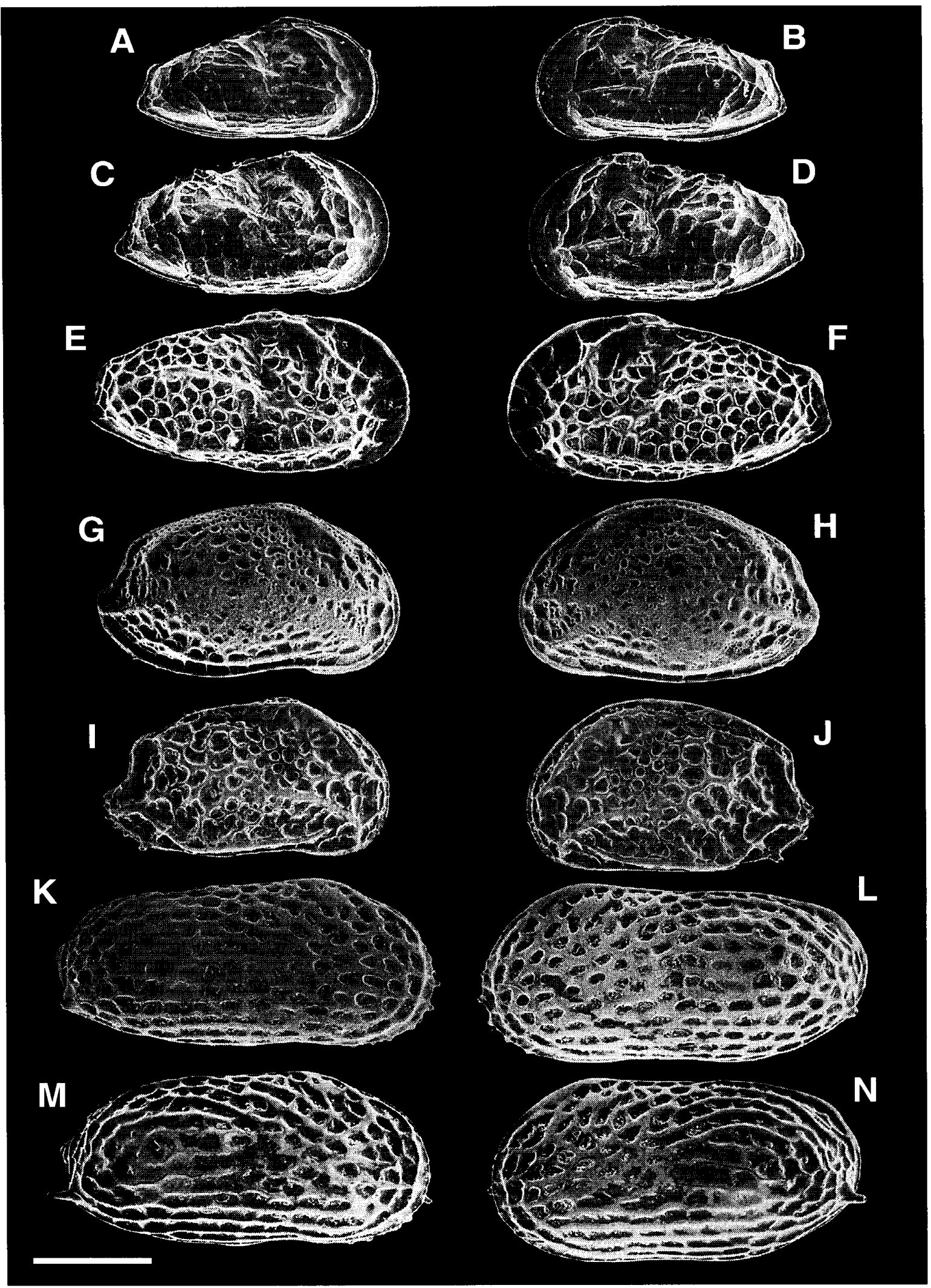


margin with several denticles. Ventro-lateral alae gently curved and with pronounced ridge terminating medially on caudal process. In dorsal view, marginal rim relatively narrow. Left valve somewhat higher than right.

Remarks. This species inhabits the algal zone of rocky shores (Ikeya and Hamada 1990). Only dead specimen was found in the present study area, at loc.5. The specimen is probably allochthonous.

\section{Bicornucythere bisanensis (Okubo, 1975)}

(Fig. 11K-N)

Cythere hodgii: Brady 1880: 94-95, pl. 25, fig. 1a-d. [nec Brady, 1866]

Cythereis hodgei [sic]: Kajiyama 1913: 13, pl. 1, figs 70, 71. [nec Brady, 1866]

Leguminocythereis hodgii: Ishizaki 1968: 25-26, pl. 5, figs 3, 4; 1969: 219, pl. 25, fig. 15, pl. 26, fig. 7; 1971: 84, pl. 3, figs 6, 7; 1972: 697-707, pl. 7, figs 1-13, pl. 8, figs 1-10. [nec Brady, 1866]

Leguminocythereis? hodgii: Ishizaki 1975: 245-249, pls 1, 2, text-fig. 2. [nec Brady, 1866]

Leguminocythereis bisanensis Okubo, 1975: 26-31, text-figs 2a-1, 3a-j; Ishizaki 1976, pl. 1.

Ruggieria (Keijella) bisanensis: Hanai et al. 1977: 52.

Keijella bisanensis: Abe 1983, pls 26, 27; Abe 1985, fig. 1 (only lower three), text-fig. 1; Wang and Zhang 1987, pl. 2, figs 15, 16; Wang, Q. et al. 1988, pl. 1, fig. 6.

Bicornucythere bisanensis: Schornikov and Shaitarov 1979: 45-47, pls 1, 2; Okada 1981, figs 1-3; Ikeya 1982, fig. 1876; Okada 1982a, figs 1-12; 1982b, text-figs 1-4, 6-11, 13-16, pls 16-30; Ishizaki 1984, pl. 1 (8); Ikeya et al. 1985, pl. 5, fig. 7; Ishizaki and Matoba 1985, pl. 2, fig. 5; Wang and Bian 1985, pl. 15, fig. 11; Wang, Min, and Yunhua 1985, pl. 11, fig. 17; Wang and Zhao 1985, pl. 7, fig. 17; Zhao et al. 1985, pl. 20, fig. 1; Ikeya et al. 1987, pl. (1), figs 12, 13; Bodergat and Ikeya 1988: 421, textfig. 4c; Paik and Lee 1988, pl. 3, fig. 1; Wang, P.-X. et al. 1988: 251, pl. 45, figs 7-9; Zhao and Wang 1988, pl. 1, fig 10; Ishizaki 1990, fig. 1 (4); Takayasu et al. 1990, fig. 8; Yajima and Lord 1990, fig. 4 (3); Ikeya and Itoh 1991, fig. 12A; Ikeya 1993, fig. 3 (3A-E); Ikeya and Shiozaki 1993: 17, fig. 2 (3A-E); Ishizaki et al. 1993, fig. 7B; Kamiya and Nakagawa 1993, pl. 4, fig. 11; Kamiya et al. 1996, pl. 4, fig. 5; Ozawa 1996, pl. 2, fig. 2; Irizuki et al. 1998, fig. 3 (2); Tanaka et al. 1998, text-fig. 6, pl. 1, fig. 8; Yamane 1998, pl. 2, fig. 4; Fujiwara et al. 2000, fig. 3; Irizuki et al. 1999, fig. 1 (B-2); Irizuki and Hosoyama 2000, fig. 3 (13).

Diagnosis. Carapace outline rectangular-ovate in lateral view. Anterior margin evenly rounded and slightly depressed ventrally, with 3-8 marginal pore denticles on ventral half of that margin. Large posterior spine directed obliquely downward, without pore canal. Posterior produced to form modest caudal process. Strong reticular ornamentation present over most of carapace surface arranged in rows running subparallel to postero-dorsal, posterior, and ventral margins, and obliquely to dorsal and anterior margins over antero-dorsal third of carapace.

Remarks. Juveniles show morphological variation in carapace ornamentation (Ishizaki 1975; Abe 1983) and occasionally there are two or three branching spines on the posterior margin (Abe 1983). Only dead specimens (empty carapaces 
or separated valves) were found in the present study area. They are probably allochthonous.

Angulicytherura? miii (Ishizaki, 1969)

(Figs 12, 13A-D)

Tetracytherura miii Ishizaki, 1969: 216-217, pl. 26, figs 10, 11, pl. 24, figs 1-3; 1971: 79, pl. 2, fig. 17.

Cytherura? miii: Hanai et al. 1977: 54; Kamiya and Nakagawa 1993, pl. 5, figs 5, 6; Yajima et al. 1985, pl. 1, figs 3, 6 .

Cytherura miii: Takayasu et al. 1990, fig. 11; Tsukagoshi and Kamiya 1996: 361, fig. $13 \mathrm{E}-\mathrm{H}$.

Angulicytherura miii: Tsukagoshi and Parker 2000, fig. 5C, D

Diagnosis. Carapace surface with obvious reticulation pattern composed of long longitudinal carinae and short latitudinal muri (Figs 12A, B, 13A-D). Sexual dimorphism of carapace relatively great: male longer and higher in posterior half than female. In copulatory organ (Fig. 12J), basal capsule almost circular and distal lobe elongate with 3 clasping apparatuses: 2 of them relatively long and curved, with outer one stout and inner one thin; other 1 short, derived from base of distal lobe; long copulatory duct with single coil.

Description. Antennule (Fig. 12C): 6 articulated segments; 6th segment bearing long seta, stout seta with serrations, and long, stout seta with short, fine hairs in distal part; numerous hairs present on anterior margin from 2nd to 5th segments. Antenna (Fig. 12D): 5 articulated segments; spatula-like seta present at distal end of 3rd segment; 5th segment bearing 2 stout, claw-like setae distally. Mandible (Fig. 12E, E'): 6 segments; 1st to 3rd segments of endopodite almost fused; coxa bearing teeth, with short, plumose seta on anterior distal margin; basis bearing exopodite reduced to feathery long seta; 2 plumose setae, one of them bifid, at distal-ventral end of basis; 1st segment of endopodite bearing 3 plumose setae and long seta with numerous spines; 2nd segment bearing 2 plumose setae and 2 long simple setae at distal end; 3rd segment bearing simple seta and stout seta, latter with row of short hairs; 4th segment bearing 2 claw-like setae and slender seta at distal end. Maxillule (Fig. 12F, F'): thin branchial plate with 17 setae (1 of them extremely reduced); basal podomere bearing palp and 3 endites, palp with 8 setae including 1 with spatula-like end, endites bearing 6, 7, and 5 setae, respectively. Thoracic legs (Fig. 12G-H): 1st and 2nd thoracic legs 4-segmented and terminating in claw-like seta with short, fine hairs on distal part; 3rd leg 5-segmented and terminating in slender, claw-like seta with short, fine hairs on distal part.

Remarks. Genus Angulicytherura was proposed by Schornikov and Dolgov (1995). A spoon-like sense organ on the antenna, which is one of diagnostic features of the genus, was observed in the present specimens. This species appeared as living specimens only in the cold season, in January and March. 


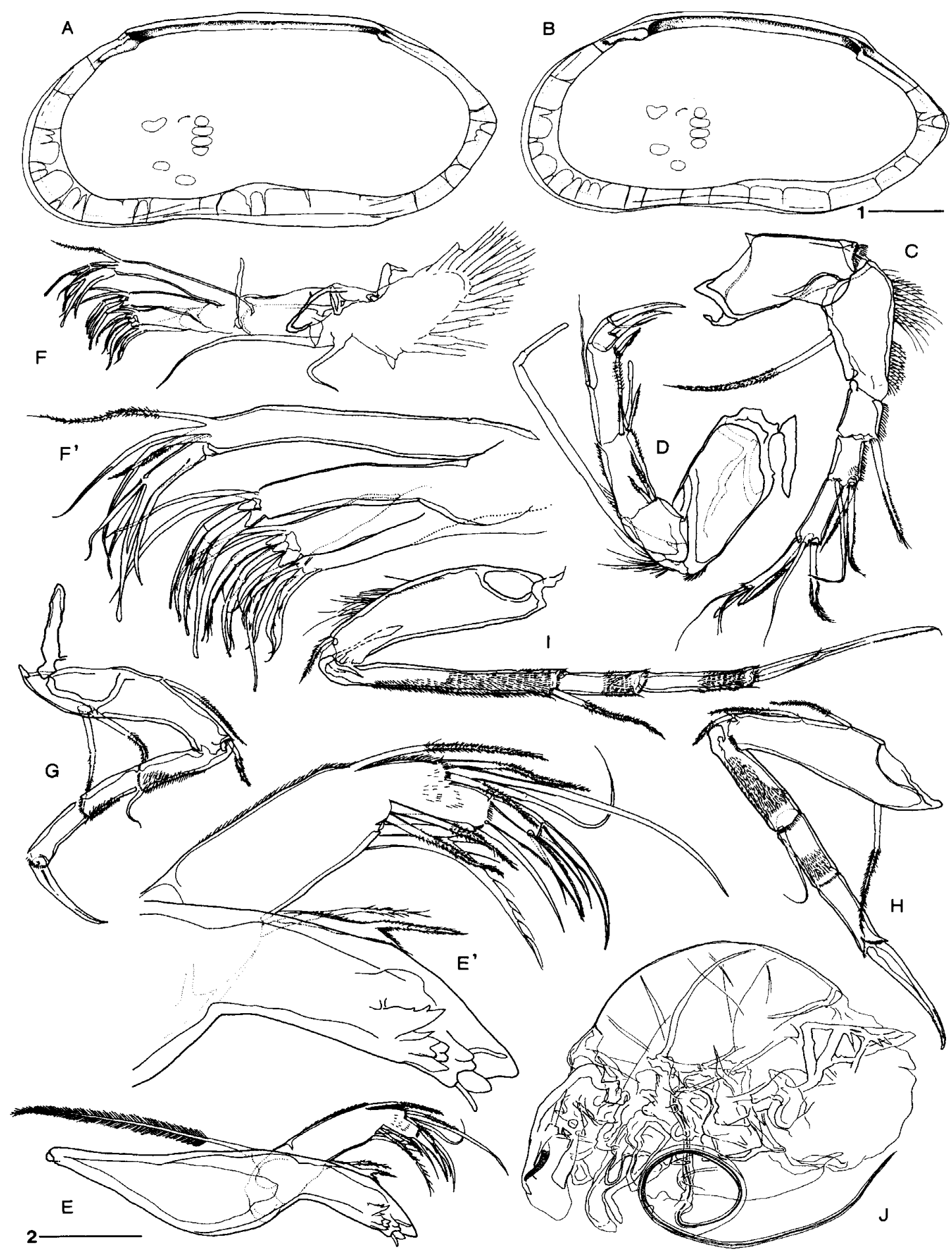

Fig. 12. Angulicytherura? miii (Ishizaki, 1969). A, internal view of male RV; B, internal view of female RV; C, antennule; D, antenna; E, mandible; F, maxillule; G, first thoracic leg; H, second thoracic leg; I, third thoracic leg; J, copulatory organ of male; E' and F', enlarged details of $\mathrm{E}$ and F, respectively. A, SUM-CO-1163 (male); B, SUM-CO-1164 (female); C, D, and F-J, SUM-CO-1165 (male); E, SUM-CO-1166 (male). Scale bar $1=100 \mu \mathrm{m}$ for A and B, scale bar $2=50 \mu \mathrm{m}$ for $\mathrm{C}-\mathrm{I}, 20 \mu \mathrm{m}$ for E' and F', $90 \mu \mathrm{m}$ for $\mathrm{J}$. 
Hemicytherura tricarinata Hanai, 1957

(Fig. 13G, H)

Hemicytherura tricarinata Hanai, 1957b: 25-26, pl. 2, fig. 3a, b; Ishizaki 1968: 20, pl. 4, fig. 13; Okubo 1980a: 16-18, figs 1e, f, 2i-1, 6; Hou et al. 1982: 176-177, pl. 74, fig. 18, text-fig. 38a, b; Ikeya 1982, fig. 1881a, b; Ikeya et al. 1985, pl. 5, figs 17-19; Kamiya 1988, text-fig. 5 (10); 1989, fig. 4 (10); Yajima and Lord 1990, fig. 5 (8); Tsukagoshi et al. 1994: 49, pl. 2/27, figs 1-8; Yamane 1998, pl. 5, fig. 7; Irizuki and Hosoyama 2000, fig. 3 (14).

Diagnosis. Carapace small, thick, and elongate subrhomboidal, highest in lateral view approximately $1 / 3$ from anterior end. Central latitudinal ridge branching to connect with 3 dorsalwards ridges and 2 ventralwards ridges. Marginal ridge continuous except around anterior margin. These ridges outlining several large reticulations. Caudal process well developed, especially on left valve.

Remarks. Only dead specimens (empty carapaces or separated valves) were found in the study area (Loc. 6). They are likely allochthonous.

\section{Hemicytherura sp.}

(Fig. 13E, F)

Hemicytherura kajiyamai: Okubo 1980a: 14-16, figs 1c, 1d, 2e-h, 5; Kamiya 1988, text-

fig. 5 (9); 1989: 79, fig. 4 (9). [nec Hanai, 1957]

Hemicytherura sp. A: Lee 1990: 321-322, pl. 27, figs 3, 4.

Diagnosis. Small, thick and subrhomboidal carapace. Highest point in lateral view at middle. Anterior margin bearing 4 to 5 small spine-like processes on lower half. Postero-most end with well-developed caudal process. Three strong ridges running obliquely downwards in anterior half. Several large round fossae in center and posterior half. Large elongate fossae between ridges in anterior half. Most of fossae have some fine inner ridges.

Remarks. Hemicytherura kajiyamai Hanai, 1957 resembles this species but it is distinguished by having a strong ala at the postero-ventral end and by the pattern of fossae. Only dead specimens (carapaces without soft part or separated valves) were found in the study area (Loc. 18). They are likely allochthonous.

\section{Semicytherura wakamurasaki Yajima, 1982}

(Figs 13I-L, 14)

Semicytherura wakamurasaki Yajima, 1982: 218, 220, pl. 14, figs 1-8, 17, text-fig. 16-1,

2; Ikeya et al. 1985, pl. 6, figs 5, 6; Wang, P.-X. et al. 1988: 263, pl. 51, figs 11-16;

Ikeya and Itoh 1991: 141, fig. 23C.

Semicytherura? miurensis: Ikeya 1982, fig. 1882b-d. [nec Hanai, 1957]

Diagnosis. Small-sized species within the genus. Dorsal margin of carapace arched and highest in lateral view at middle. Approximately 12 longitudinal ridges 


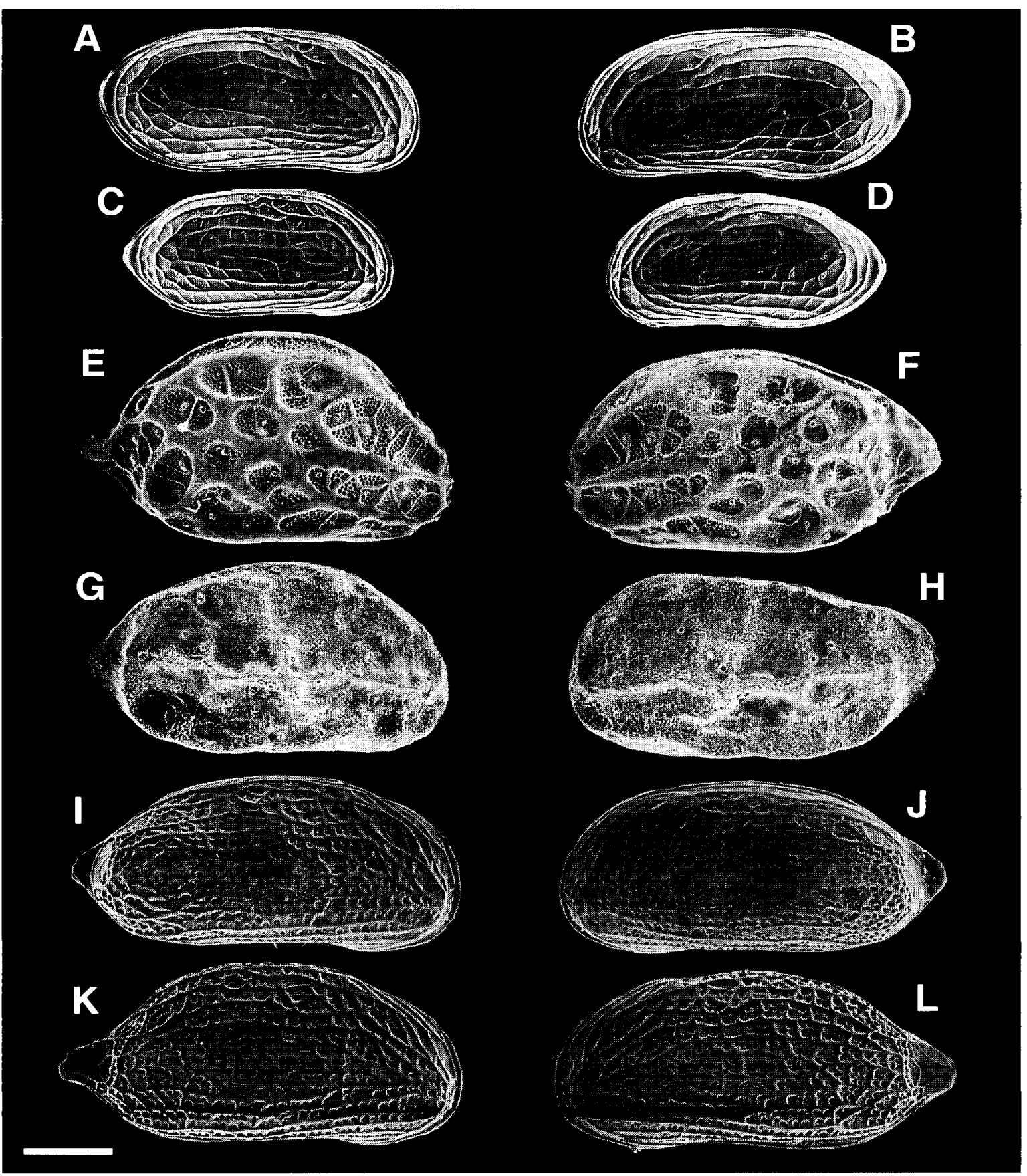

Fig. 13. Angulicytherura? miii (Ishizaki, 1969) (A-D), Hemicytherura sp. (E, F), H. tricarinata Hanai, 1957 (G, H), and Semicytherura wakamurasaki Yajima, 1982 (I-L). A, male carapace in external right lateral view (SUM-CO-1159); B, male carapace in external left lateral view (SUM-CO-1160); C, female carapace in external right lateral view (SUM-CO-1161); D, female carapace in external left lateral view (SUM-CO-1162); E, F, RV and LV in external lateral view (SUM-CO-1167); G, H, RV and LV in external lateral view (SUM-CO-1168); I, male RV in external lateral view (SUM-CO-1169); J, male carapace in external left lateral view (SUM-CO-1170); $\mathrm{K}, \mathrm{L}$, female RV and LV in external lateral view (SUM-CO-1171). Scale bar $=200 \mu \mathrm{m}$ for A-D, $100 \mu \mathrm{m}$ for $\mathrm{E}-\mathrm{L}$. 


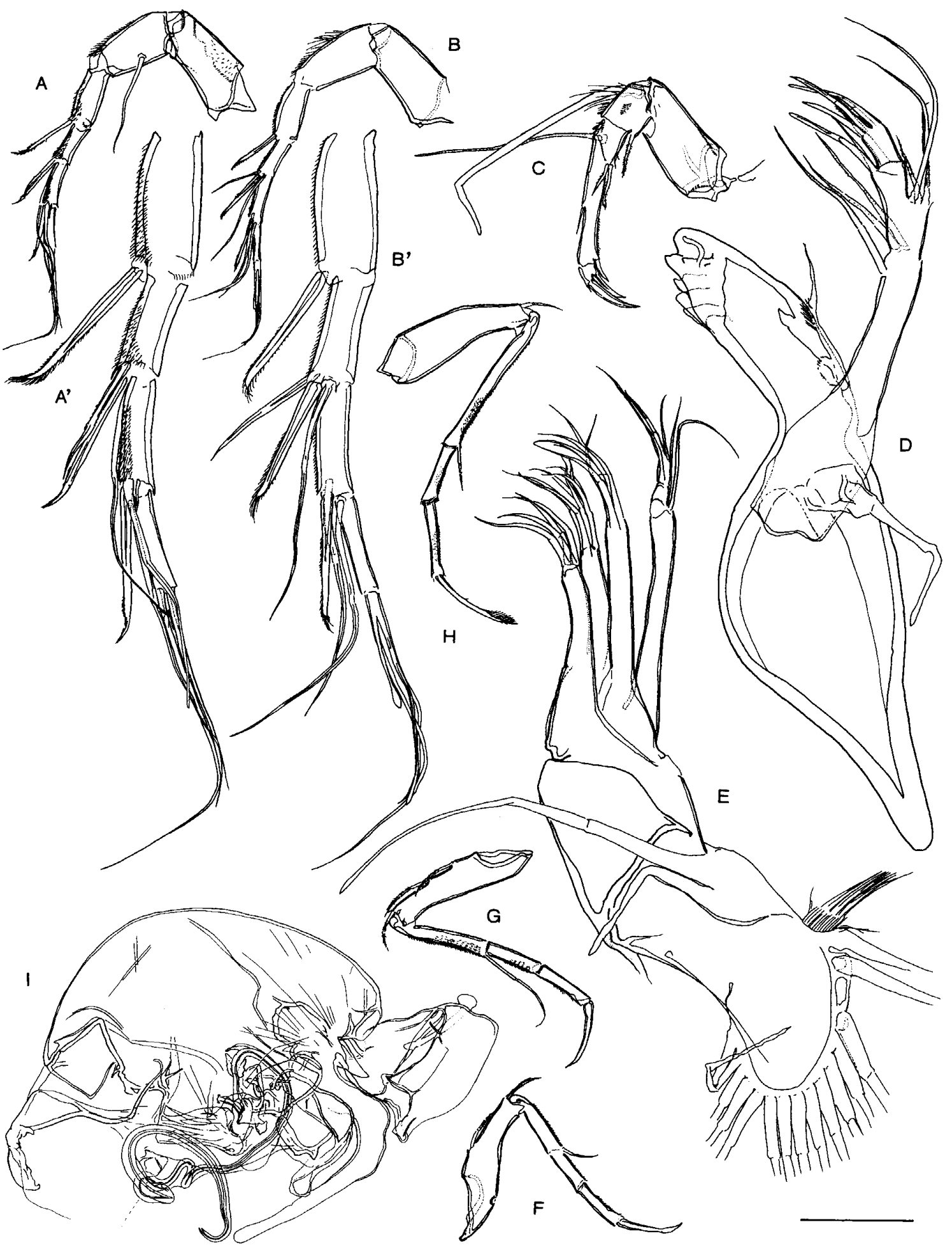

Fig. 14. Semicytherura wakamurasaki Yajima, 1982. A, B, antennule; C, antenna; D, mandible; E, maxillule; F, first thoracic leg; G, second thoracic leg; $H$, third thoracic leg; I, copulatory organ of male; A', B', enlarged details of A, B, respectively. A-H, SUM-CO-1172 (male); I, SUMCO-1173 (male). Scale bar $=50 \mu \mathrm{m}$ for A-C and F-H, $20 \mu \mathrm{m}$ for A', B', D, and E, $40 \mu \mathrm{m}$ for I. 


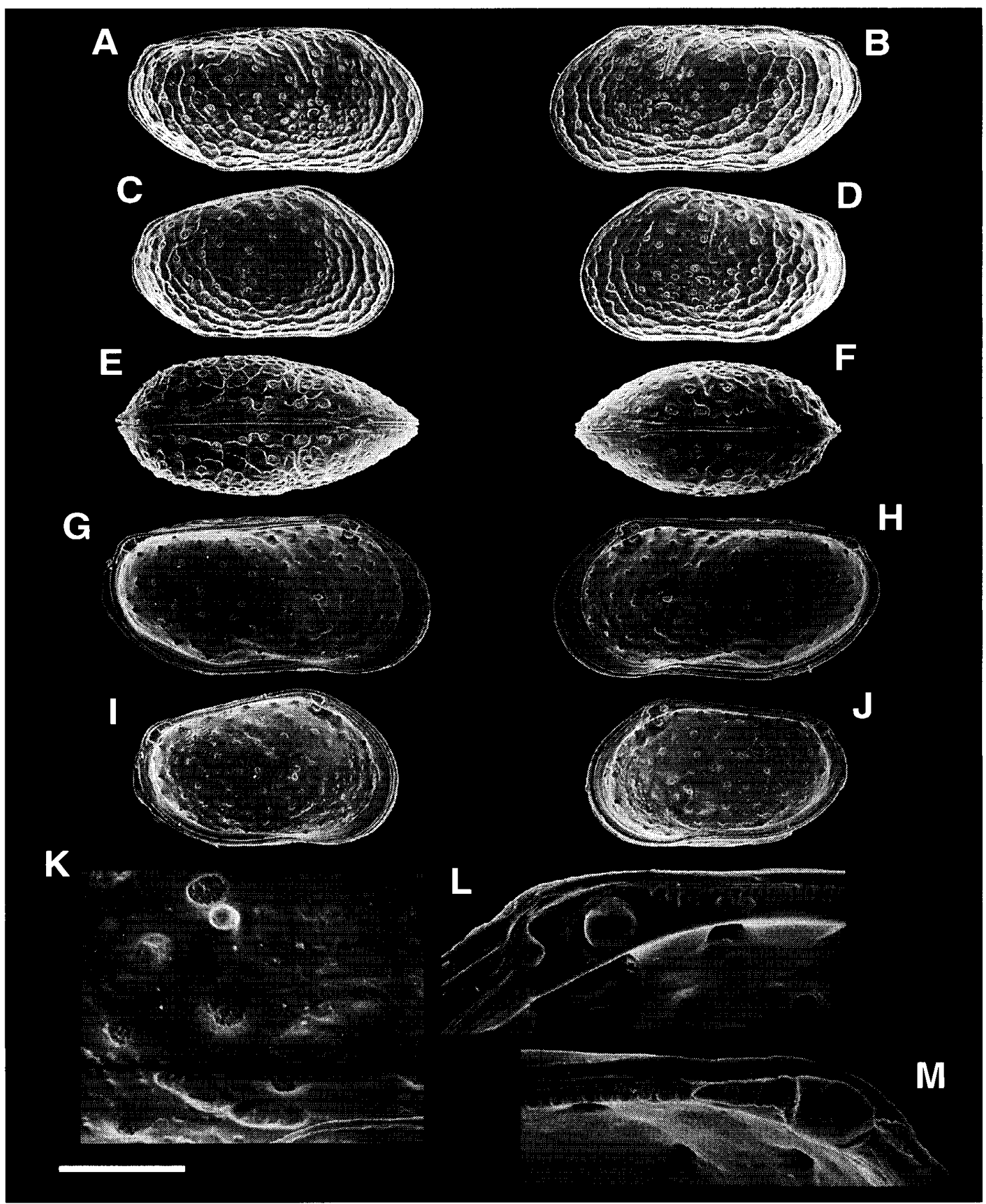

Fig. 15. Loxoconcha kosugii n. sp. A, male carapace in external right lateral view (holotype, SUM-CO-1174); B, male carapace in external left lateral view (paratype, SUM-CO-1175); C, female carapace in external right lateral view (paratype, SUM-CO-1176); D, female carapace in external left lateral view (paratype, SUM-CO-1177); E, male carapace in external dorsal view (paratype, SUM-CO-1178); F, female carapace in external dorsal view (paratype, SUM-CO1179); G, male LV in internal lateral view (paratype, SUM-CO-1180); H, male right valve in internal lateral view (paratype, SUM-CO-1181); I, female left valve in internal lateral view 
running parallel at midlength and converging anterior and posterior ends. Male copulatory organ with coiled copulatory duct and 2 clasping apparatuses, one large and L-shaped, other one small (Fig. 14I); distal lobe subtriangular with small, swollen-tipped process.

Description. Antennule (Fig. 14A, A', B, B'): 6 articulated segments; 6 th segment bearing 2 long, simple setae and branched seta terminating in spatula-like ends and in rounded head, respectively (Fig. 14B'); 3rd segment bearing stout seta distally; 4th segment bearing 2 stout setae and long, fine seta distally; 5 th segment bearing stout seta and 2 long, fine setae distally. Antenna (Fig. 14C): 4 articulated segments; 3rd segment bearing vestiges of articulation, with long seta on proximal part of anterior margin; 4th segment bearing 2 claw-like setae at distal end. Mandible (Fig. 14D): 5 segments; coxa bearing poorly developed teeth and with short process at anterior end; thin seta with hairs on anterior margin of coxa; basis bearing exopodite reduced to soft seta; distal segment of endopodite bearing 4 setae at distal end. Maxillule (Fig. 14E): thin branchial plate with 18-19 seta and bundle of hairs; basal podomere bearing palp and 3 endites, palp with 6 setae, endites bearing 6, 7, and 4 setae, respectively. Thoracic legs (Fig. 14F-H): all 3 legs 4segmented; 1st and 2nd legs terminating in long, unguiform seta; 3rd one terminating in seta with hairs arranged like comb.

Remarks. The soft parts of this species are illustrated herein for the first time.

\section{Loxoconcha kosugii n. sp.}

(Figs 15, 16)

Loxoconcha sp.: Tsukagoshi and Kamiya 1996: 366, fig. 18E-H.

Types. Holotype, SUM-CO-1174 (complete male carapace, length: $0.640 \mathrm{~mm}$, height: $0.341 \mathrm{~mm}$, width: $0.316 \mathrm{~mm}$ ); paratypes, SUM-CO-1175 (complete male carapace), SUM-CO-1176 (complete female carapace), SUM-CO-1177 (complete female carapace), SUM-CO-1178 (complete male carapace), SUM-CO-1179 (complete female carapace), SUM-CO-1180 (LV of male), SUM-CO-1181 (RV of male), SUM-CO-1182 (LV of female), SUM-CO-1183 (RV of female), SUM-CO-1184 (RV, LV, and soft parts of male), SUM-CO-1185 (RV and LV of female), SUM-CO-1186 (soft parts of male), and SUM-CO-1187 (RV, LV, and soft parts of male).

Etymology. Named in honor of the late Dr. Masato Kosugi (Nihon University).

Type locality. Loc. 24: creek of delta swamp at Mouth of Obitsu River, Kisarazu City, Chiba Prefecture, Japan $\left(35^{\circ} 24.6^{\prime} \mathrm{N}, 139^{\circ} 53.6^{\prime} \mathrm{E}\right)$, sandy mud bottom, water depth $c a 5 \mathrm{~cm}$ at lowest low tide.

Diagnosis. Carapace rhomboidal in lateral view, dorsal and ventral margins straight and almost parallel (Fig. 15A-D). Sexual dimorphism strong. Carapace of male elongate with posterior half inflated. Surface covered with obvious reticulations and sieve-type pore systems with wide openings arranged in concentric rows

(paratype, SUM-CO-1182); J, female RV in internal lateral view (paratype, SUM-CO-1183); K, muscle scars of female RV (paratype, SUM-CO-1183); L, M, anterior and posterior elements of hingement on male RV (paratype, SUM-CO-1181). Scale bar $=300 \mu \mathrm{m}$ for A $-\mathrm{J}, 50 \mu \mathrm{m}$ for K-M. 


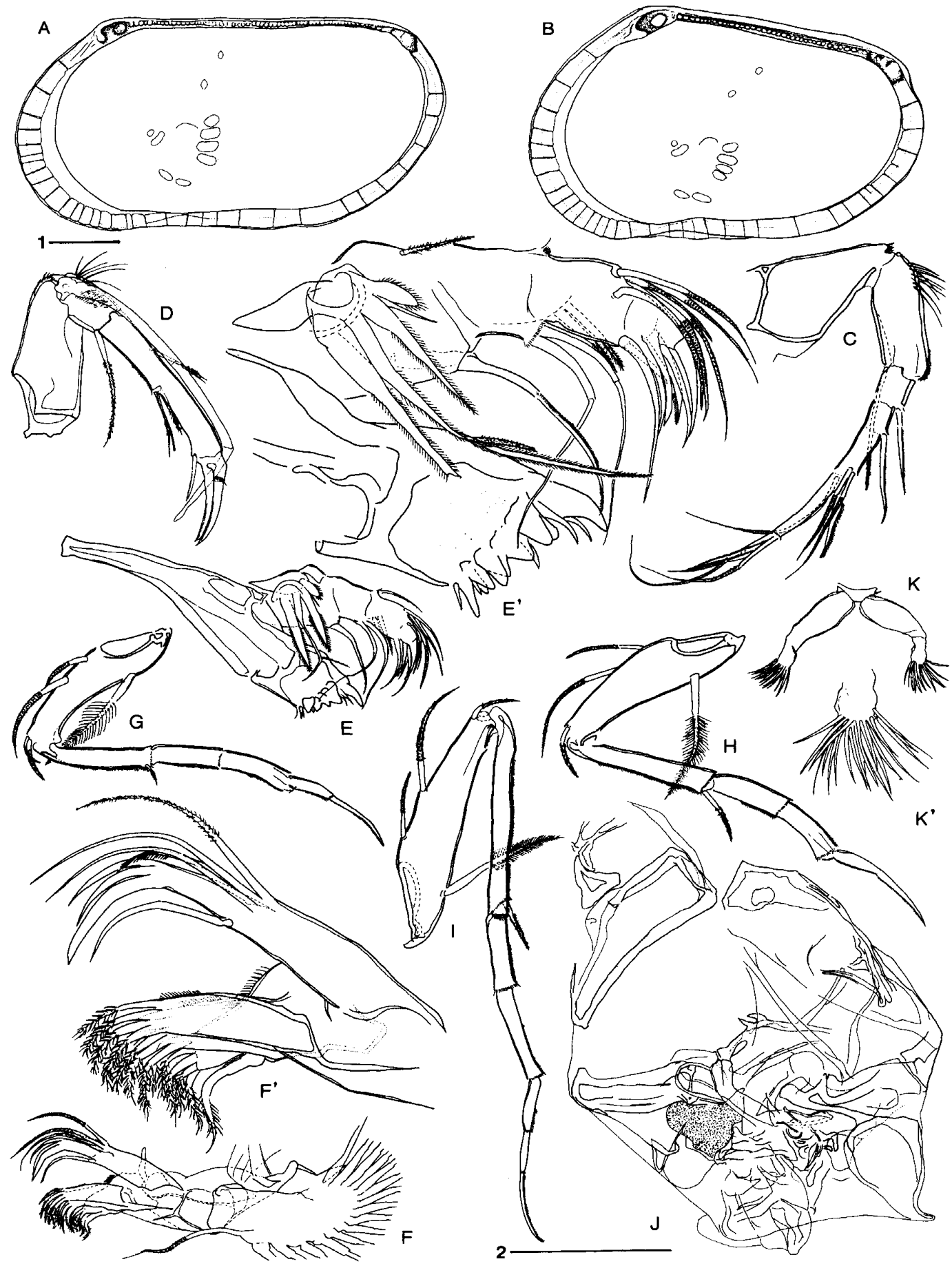

Fig. 16. Loxoconcha kosugii n. sp. A, internal view of male RV; B, internal view of female RV; C, antennule; D, antenna; E, mandible; F, maxillule; G, first thoracic leg; H, second thoracic leg; I, third thoracic leg; J, copulatory organ of male; K, brush-shaped organ; E', F', and $\mathrm{K}$, enlarged details of E, F, and K, respectively. A, SUM-CO-1184 (paratype, male); B, SUMCO-1185 (paratype, female); C-I and K, SUM-CO-1186 (paratype, male); J, SUM-CO-1187 (paratype, male). Scale bar $1=100 \mu \mathrm{m}$ for A and B. Scale bar $2=140 \mu \mathrm{m}$ for $\mathrm{J}, 100 \mu \mathrm{m}$ for $\mathrm{C}-\mathrm{I}$ and $\mathrm{K}, 40 \mu \mathrm{m}$ for $\mathrm{E}^{\prime}, \mathrm{F}^{\prime}$, and $\mathrm{K}$ '. 
running subparallel to anterior, ventral, and posterior margins. Marginal infoldment narrow (Fig. 15G-J), especially in posterior half. In male copulatory organ (Fig. 16J), large distal lobe thin especially along distal margin and making tip. Large, thin clasping apparatus overlapping distal lobe with distal end extending outside distal margin of latter. Copulatory duct very fine, short, and folded inside inner margin of distal lobe.

Description. Hingement (Fig. 15L, M): gongylodont; on RV, single large tooth surrounding by depression in anterior element; numerous fine teeth in median element; few small teeth and 1 large tooth in posterior element. Muscle scars (Figs $15 \mathrm{~K}, 16 \mathrm{~A}, \mathrm{~B}): 2$ separate frontal scars; 2 elongate mandibular scars; 4 adductor scars. Very narrow vestibules anteriorly and posteriorly. Antennule (Fig. 16C): 6 segments, with 4 th and 5th segments fused; distal segment bearing 2 long and 2 short setae. Antenna (Fig. 16D): 4 articulated segments; 4th segment bearing 2 claw-like setae with serrations at distal end and on ledge, respectively. Mandible (Fig. 16E, E'): 5 articulated segments; coxa bearing teeth on medial edge and plumose seta on anterior distal margin; basis bearing exopodite as bunch of 4 plumose setae (one of them extremely reduced) and 1 short, simple seta; 1st segment of endopodite bearing 2 short and 1 medium-long plumose setae, and 2 long setae (one of them with short, fine hairs arranged in row); 2nd segment of endopodite bearing 6 setae on ledge and 2 setae at distal end; 3rd segment of endopodite bearing 4 simple setae and 1 short, plumose seta. Maxillule (Fig. 16F, F'): thin branchial plate with 16 plumose setae; basal podomere bearing palp and 3 endites; palp and each endite with several equal-length, plumose setae. Thoracic legs (Fig. 16G-I): all 3 legs 4-segmented and similar in shape; joint-like constrictions with short, fine hairs in distal claw-like seta.

Remarks. The records presented herein are from the lowest salinity site for any extant species of Loxoconcha reported from Japan. This species resembles $L$. uranouchiensis Ishizaki, 1968, but it has more sharp muri on its carapace and more elongate distal lobe on the male copulatory organ.

\section{Loxoconcha pulchra Ishizaki, 1968}

(Figs 17, 18)

Loxoconcha pulchra Ishizaki, 1968: 31, pl. 1, fig. 16, pl. 7, figs 19, 20; Ikeya et al. 1985, pl. 7, figs 1-5; Kamiya and Nakagawa 1993, pl. 6, figs 4, 5; Irizuki and Matsubara 1994, pl. 1, fig. 18; Yamane 1998, pl. 6, fig. 5; Irizuki and Hosoyama 2000, fig. 3 (16).

Not Loxoconcha pulchra: Tsukagoshi et al. 1994, pl. 2/28, figs 1-6. [Loxoconcha sp., undescribed species]

Diagnosis. Carapace rhomboidal in lateral view (Fig. 17A-D). Upper half of posterior margin straight and oriented obliquely upward. Modest ala developed ventrally. Carapace surface covered with numerous fine pits and scattered sievetype pore systems. Hingeline almost straight. Marginal infoldment narrow. In male copulatory organ (Fig. 18H), large distal lobe thin especially along distal margin. Thumb-like clasping apparatus precisely overlapping distal part of distal lobe. Copulatory duct fine and folded. 


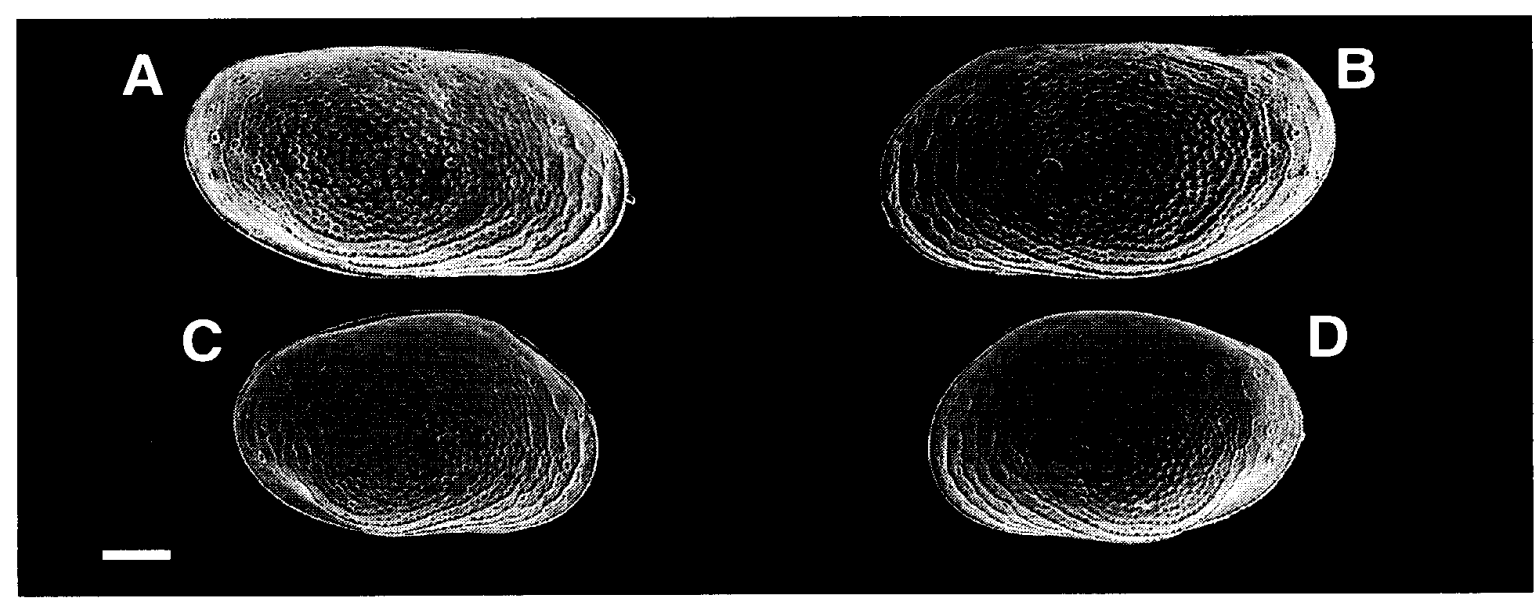

Fig. 17. Loxoconcha pulchra Ishizaki, 1968. A, male carapace in external right lateral view (SUM-CO-1188); B, male carapace in external left lateral view (SUM-CO-1189); C, female carapace in external right lateral view (SUM-CO-1190); D, female carapace in external left lateral view (SUM-CO-1191). Scale bar $=100 \mu \mathrm{m}$.

Description. Antennule (Fig. 18A): 6 segments, with 4th and 5th segments fused; distal segment bearing 3 simple setae and claw-like seta, latter with fine, short hairs on distal part of anterior margin. Antenna (Fig. 18B): 4 articulated segments; stout seta with short, fine hairs at distal end of third segment; 4th segment bearing 2 claw-like setae with serrations at distal end and on ledge, respectively. Mandible (Fig. 18C, C'): 5 segments; coxa bearing teeth, short, simple hair, and 2 comb-like structures; basis bearing exopodite as small branchial plate with few soft setae; first segment of endopodite bearing 3 long setae and 2 short setae; 2nd segment bearing 6 long setae on ledge, two simple setae and 1 stout, plumose seta at distal end; 3rd segment bearing 2 stout setae and 1 plumose seta at distal end. Maxillule (Fig. 18D, D'): thin branchial plate with 16 setae; basal podomere bearing palp and 4 endites; palp with 5 long setae and 3 stout setae; distal 3 endites bearing 6,7 , and 4 setae, respectively; proximal endite bearing long hairs arranged in 2 rows and terminating in spatula-like head. Thoracic legs (Fig. 18E-G): all 3 legs 4segmented and similar in shape; all legs terminating in claw-like seta with short, fine hairs and joint-like constrictions.

Remarks. Illustrations of the soft parts of this species are presented herein for the first time.

\section{Cytheromorpha acupunctata (Brady, 1880)}

(Fig. 19)

Cythere acupunctata Brady, 1880: 68, pl. 14, fig. 1a-h.

Cytheromorpha acupunctata: Hanai 1961a: 371, text-fig. 12, fig. 2a, b; Ishizaki 1968: 35-36, pl. 7, figs 17, 18; 1969: 220, pl. 26, figs 5, 6; 1971: 90, pl. 3, fig. 13; Okubo 1978: 90-93, figs 1a-f, 2, 4a-h; Ikeya 1982, fig. 1889a-c; 1983: 2, fig. 1 (3); Ishizaki 1984, pl. 1 (3); Ikeya et al. 1985, pl. 8, figs 7, 10-12; Ishizaki and Matoba 1985, pl. 3, figs 3, 4; Ikeya et al. 1987, pl. (1), figs 9-11; Bodergat and Ikeya 1988: 421, text-fig. 4a; Ikeya and Ueda 1988: 329, pl. 1, figs a-m, pl. 2, figs a-o, pl. 3, figs 1-3, text-figs 6, 


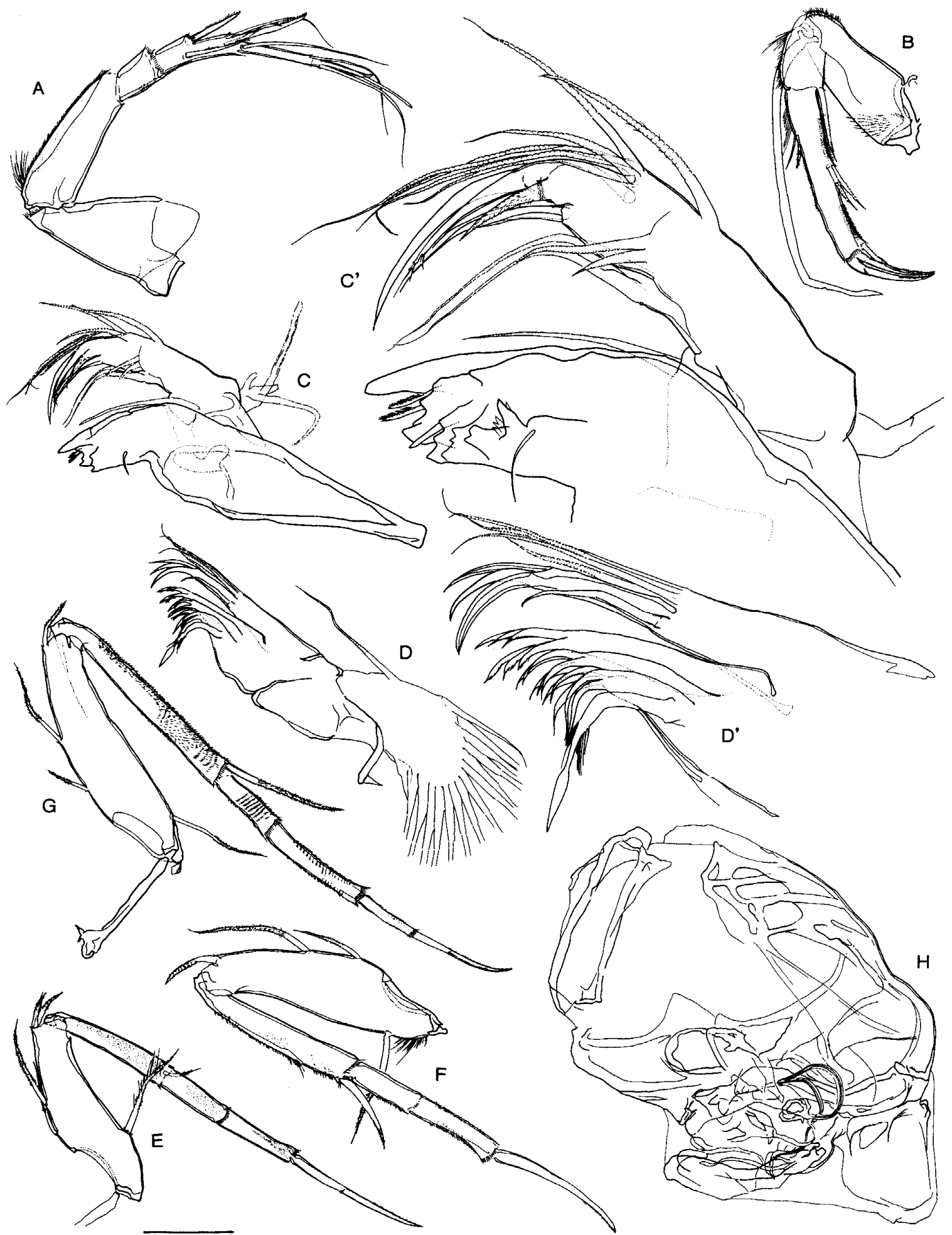

Fig. 18. Loxoconcha pulchra Ishizaki, 1968. A, antennule; B, antenna; C, mandible; D, maxillule; E, first thoracic leg; F, second thoracic leg; G, third thoracic leg; $\mathrm{H}$, copulatory organ of male; C' and D', enlarged details of C and D, respectively. A-H, SUM-CO-1192 (male). Scale bar $=50 \mu \mathrm{m}$ for $\mathrm{A}-\mathrm{G}, 20 \mu \mathrm{m}$ for $\mathrm{C}^{\prime}$ and $\mathrm{D}^{\prime}, 80 \mu \mathrm{m}$ for $\mathrm{H}$. 
7; Paik and Lee 1988: 552, pl. 3, fig. 19; Wang, Q. et al. 1988, pl. 1, fig. 26; Ishizaki 1990, fig. 1 (3); Takayasu et al. 1990, fig. 16; Yajima and Lord 1990, fig. $5(4,5)$; Ikeya and Itoh 1991, fig. 14C; Ikeya 1993, fig. 3 (1A-E); Ikeya and Shiozaki 1993: 17, fig. 2 (1A-E); Tsukagoshi et al. 1994, pl. 2/29, figs 1-8; Ozawa 1996, pl. 3, fig. 10; Irizuki et al. 1998, fig. 8 (10); Tanaka et al. 1998, pl. 1, fig. 5; Yamane 1998, pl. 4, fig. 6; Irizuki et al. 1998, fig. 3 (10); 1999, fig. 1 (B-3); Fujiwara et al. 2000, fig. 3; Irizuki and Hosoyama 2000, fig. 3 (15).

Cytheromorpha japonica Ishizaki, 1968: 36, pl. 9, figs 11, 12; 1969: 221, pl. 26, fig. 16; Wang and Zhang 1987, pl. 2, fig. 33; Wang, Q. et al. 1988, pl. 1, fig. 27. [Synonymized by Hanai 1977]

Diagnosis. Great sexual dimorphism evident in lateral view; males elongate, females triangular-quadrate. Highest point $1 / 3$ and $1 / 4$ from anterior end in female and male, respectively. Hingeline almost straight. Carapace surface covered with conspicuous reticulations or fine pits (large variation of carapace ornamentation known). Modest ridges in anterior and posterior zones. Sulci in post-ocular and dorsomedian areas.

Remarks. Ikeya and Ueda (1988) showed a seasonal change between coarse and fine carapace ornamentation in this species in Lake Hamana-ko. Intermediate and fine-type ornamentation appeared in the present study area.

Cytherois ikeyai n. sp.

(Figs 20, 21)

Types. Holotype, SUM-CO-1196 (compete male carapace, length: $0.266 \mathrm{~mm}$, height: $0.106 \mathrm{~mm}$, width: $0.100 \mathrm{~mm}$ ); paratypes, SUM-CO-1197 (complete male carapace), SUM-CO-1198 (complete female carapace), SUM-CO-1199 (complete female carapace), SUM-CO-1200 (complete male carapace), SUM-CO-1201 (complete female

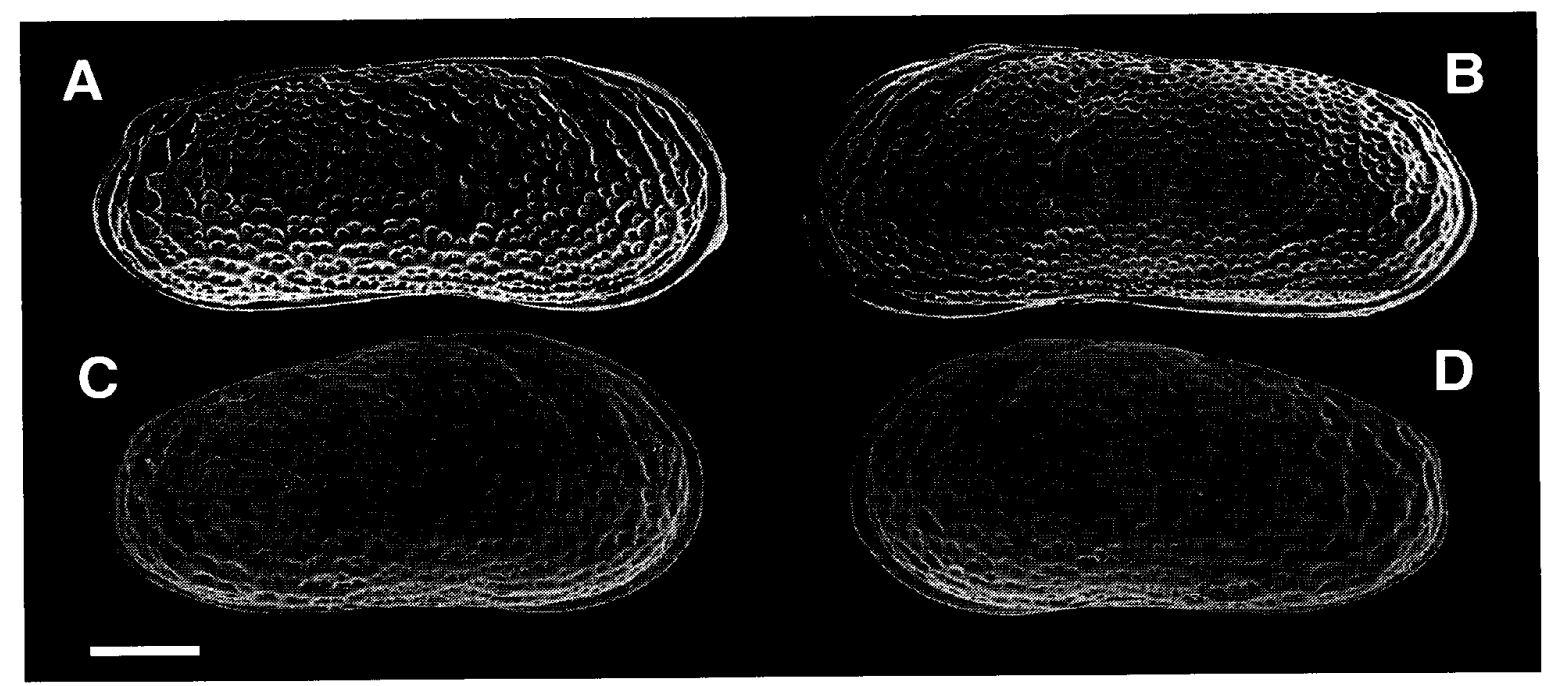

Fig. 19. Cytheromorpha acupunctata (Brady, 1880). A, male carapace in external right lateral view (SUM-CO-1193); B, male carapace in external left lateral view (SUM-CO-1194); C, D, female RV and LV in external lateral view (SUM-CO-1195). Scale bar $=100 \mu \mathrm{m}$. 
carapace), SUM-CO-1202 (LV of female), SUM-CO-1203 (RV of female), SUM-CO-1204 (RV of male), SUM-CO-1205 (RV of male), SUM-CO-1206 (RV of female), and SUMCO-1207 (soft parts of male).

Etymology. In honor of Prof. Noriyuki Ikeya (Shizuoka University).

Type locality. Loc. B: small creek within halophilous glass at mouth of Obitsu River, Kisarazu City, Chiba Prefecture, Japan $\left(35^{\circ} 24.6^{\prime} \mathrm{N}, 139^{\circ} 54.2^{\prime} \mathrm{E}\right)$, muddy sand bottom, depth ca $5 \mathrm{~cm}$ at lowest low tide.

Diagnosis. Carapace in lateral view with posterior half of dorsal margin broadly arched, anterior half straighter with pronounced change in slope (Fig. 20A-D). In male, distal segment of antennule bearing spatulate seta and 4th segment of antenna bearing sucker-like organ at distal end of inner margin (Fig. 21C, D). Male copulatory organ with almost circular capsule and flat trapezoidal distal lobe bearing leaf-like process proximally (Fig. 21J). Copulatory duct not very long and coiling once at its proximal end.

Description. Carapace thin and fragile, that of female larger than that of male in length and height. Hingement (Fig. 20J, K): lophodont; median element very long; all elements non-crenulate. Muscle scars (Figs 20I, 21A, B): each scar elongate; 2 separated mandibular scars. Vestibule well developed anteriorly and postero-ventrally. Antennule (Fig. 21C): 6 articulated segments; 2nd segment very long; 6th (distal) segment bearing 3 simple and 1 spatula-like setae. Antenna (Fig. 21D): 4 articulated segments; length of 2nd segment almost equal to that of 1st segment; 4th segment bearing 2 claw-like setae and sucker-like organ. Mandible (Fig. 21E): 5 segments with 2nd and 3rd segments of endopodite almost fused; coxa bearing poor developed teeth; basis bearing exopodite reduced to simple, long setae; 1st segment of endopodite long and lacking setae; 2nd segment bearing 5 simple setae at distal end; 3rd segment bearing 3 stout and 4 relatively thin setae at distal end. Maxillule (Fig. 21F): thin branchial plate with about 12 setae; basal podomere bearing palp and 3 endites; palp with 5 setae and each endite with 3 setae. Thoracic legs (Fig. 21G-I): all 3 legs 4-segmented and similar in shape; 2nd segment of each bearing stout setae at distal end.

Remarks. This species resembles $C$. bingoensis Okubo, 1980 in carapace outline. Okubo (1980c) did not illustrate the male copulatory organ, but the distal structure of the male second antenna of $C$. ikeyai $\mathrm{n}$. sp. is clearly distinct from that of $C$. bingoensis.

\section{Discussion}

This research compensates for the previous lack of information on intertidal brackish-water ostracod faunas in Japan. Twenty-one species of Ostracoda, including five previously undescribed species, occurred in the study area. The five species for which only valves were found probably being allochthonous, one-third of the native estuarine species we examined were thus previously undescribed. Furthermore, the soft parts of four previously described taxa have been illustrated here for the first time (previously, only their carapace morphology had been described).

Frydl (1982) studied the ostracod fauna in areas adjacent to the southern part of the present study area, specifically the Recent fauna of Tateyama Bay and fossil 


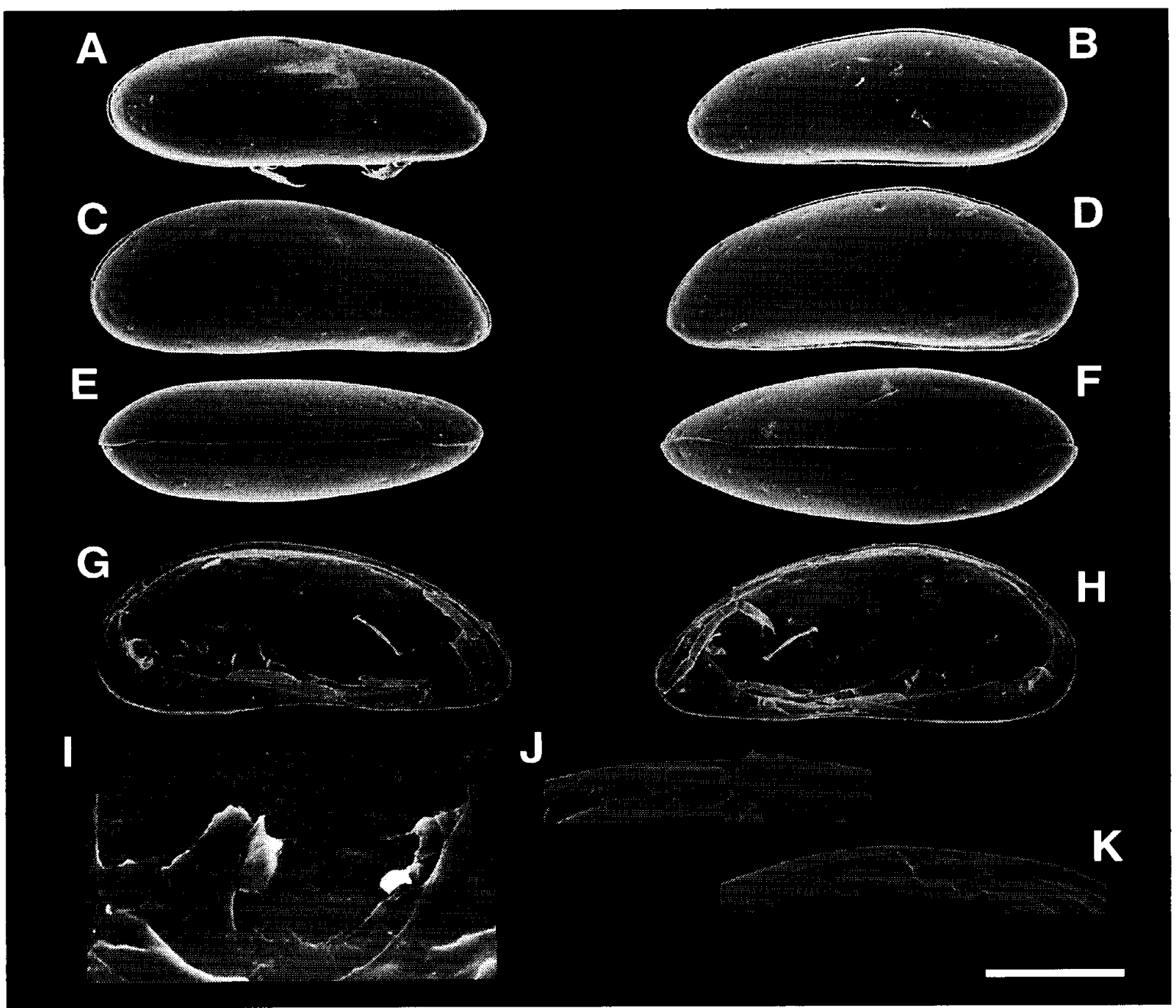

Fig. 20. Cytherois ikeyai n. sp. A, male carapace in external right lateral view (holotype, SUM-CO-1196); B, male carapace in external left lateral view (paratype, SUM-CO-1197); C, female carapace in external right lateral view (paratype, SUM-CO-1198); D, female carapace in left lateral view (paratype, SUM-CO-1199); E, male carapace in external dorsal view (paratype, SUM-CO-1200); F, female carapace in external dorsal view (paratype, SUM-CO1201); G, female left valve in internal lateral view (paratype, SUM-CO-1202); H, female right valve in internal lateral view (paratype, SUM-CO-1203); I, muscle scar of male right valve (paratype, SUM-CO-1204); J, K, hingements of female right valve (paratype, SUM-CO-1203). Scale bar $=110 \mu \mathrm{m}$ for A-H, $17 \mu \mathrm{m}$ for I, $30 \mu \mathrm{m}$ for $\mathrm{J}$ and $\mathrm{K}$.

remains in Holocene sediment from the Numa Formation. He listed 83 and 111 species from these localities, respectively. Only three species from Tateyama Bay (Spinileberis quadriaculeata, Mutilis assimilis=Robustaurila ishizakii, and Cytheromorpha acupunctata) and five species from the Holocene Numa Formation (Tanella pacifica=Ishizakiella miurensis, Spinileberis quadriaculeata, Aurila sp., Mutilas assimilis=Robustaurila ishizakii, and Cytheromorpha acupunctata) are shared with the Obitsu Estuary fauna of this study. In Tateyama Bay, sediments shallower than $5 \mathrm{~m}$ in depth were not sampled and the intertidal estuarine fauna 

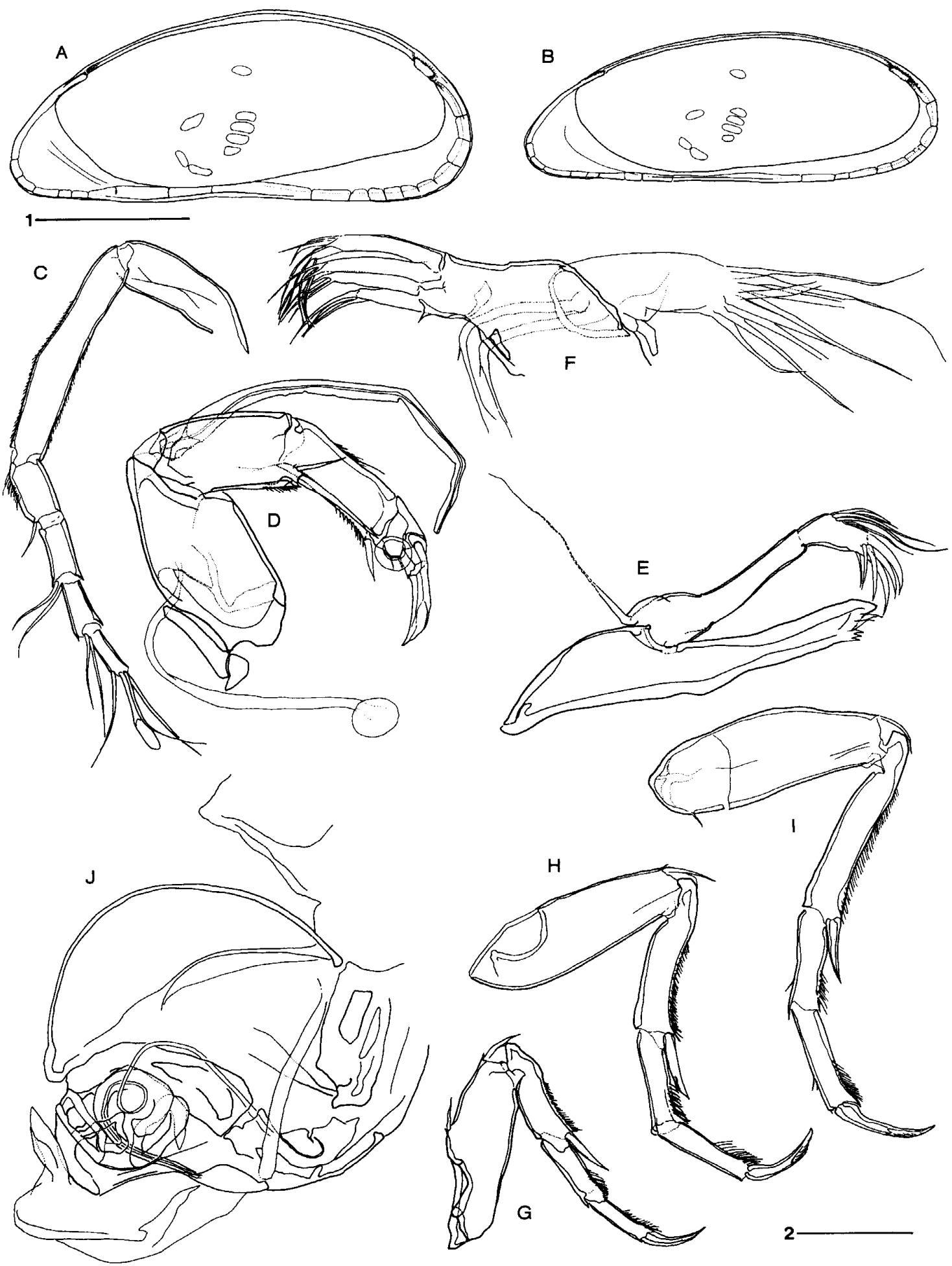

Fig. 21. Cytherois ikeyai n. sp. A, internal view of male RV; B, internal view of female RV; C, antennule; D, antenna; E, mandible; F, maxillule; G, first thoracic leg; $\mathrm{H}$, second thoracic leg; I, third thoracic leg; J, copulatory organ of male. A, SUM-CO-1205 (paratype); B, SUM-CO-1206 (paratype); C J, SUM-CO-1207 (paratype, male). Scale bar $1=10 \mu \mathrm{m}$ for A and B, scale bar $2=20 \mu \mathrm{m}$ for $\mathrm{C}-\mathrm{J}$. 


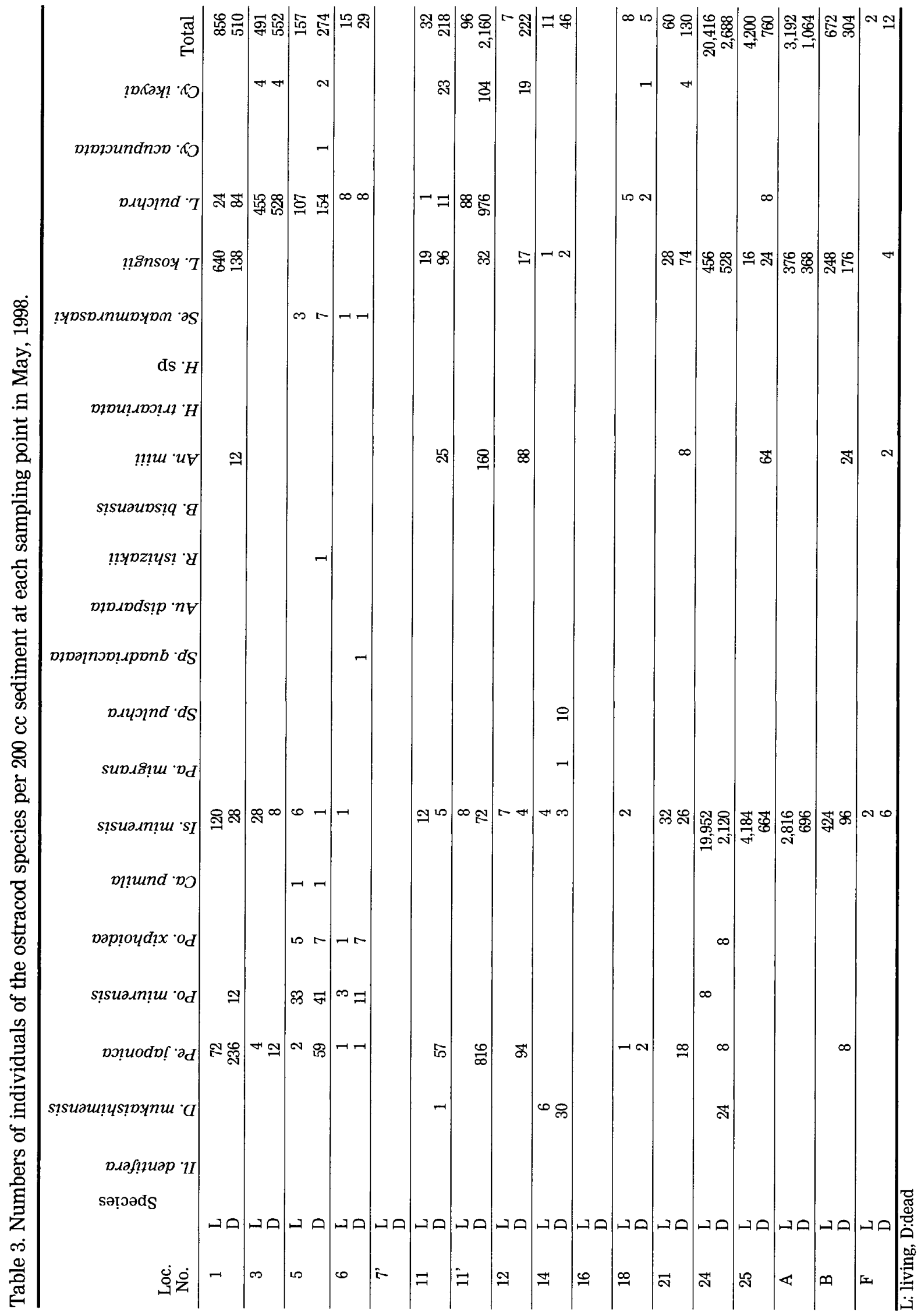


Brackish-water ostracods from Japan

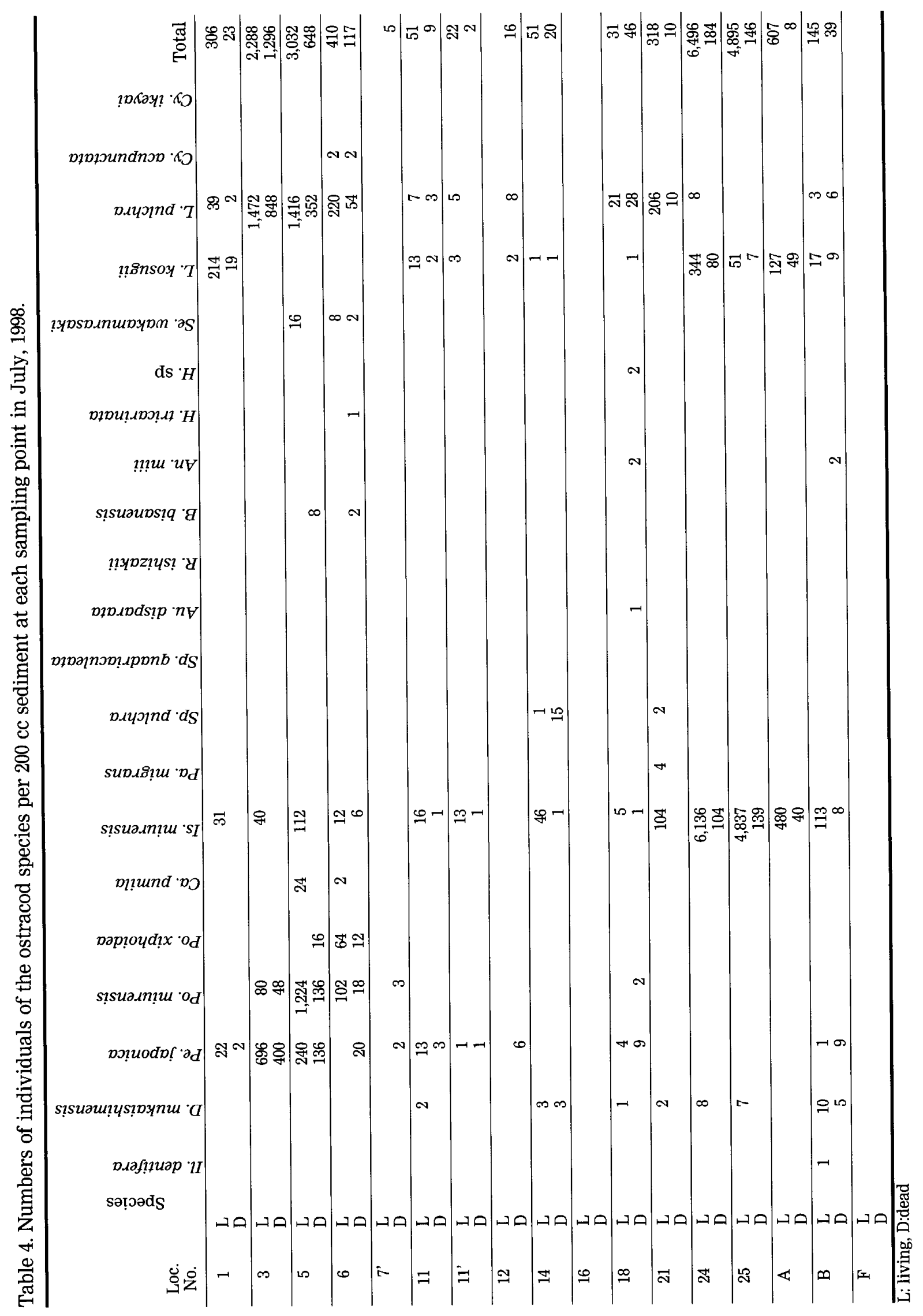


Table 5. Size dimensions, site of occurrences, and salinity range at main didtribution points (SRDP) of each species.

\begin{tabular}{|c|c|c|c|c|c|c|c|c|c|c|c|}
\hline \multirow[t]{2}{*}{ Species name } & & \multicolumn{2}{|c|}{ Length } & \multicolumn{3}{|c|}{$\begin{array}{l}\text { Dimensions (mm) } \\
\text { Height }\end{array}$} & \multicolumn{3}{|c|}{ Width } & Occurrences & \multirow{2}{*}{$\begin{array}{r}\text { SRDP } \\
\% 0\end{array}$} \\
\hline & & Av. & OR & Av. & OR & $\mathrm{N}$ & Av. & OR & $\mathrm{N}$ & (Loc. No.) & \\
\hline $\begin{array}{l}\text { Ilyocypris } \\
\text { dentifera }\end{array}$ & $\begin{array}{l}\text { Male } \\
\text { Female }\end{array}$ & $\begin{array}{l}0.67 \\
0.77\end{array}$ & $\begin{array}{l}0.60-0.70 \\
0.72-0.84\end{array}$ & $\begin{array}{l}0.38 \\
0.42\end{array}$ & $\begin{array}{l}0.36-0.39 \\
0.40-0.48\end{array}$ & $\begin{array}{l}5 \\
6\end{array}$ & $\begin{array}{l}0.26 \\
0.26\end{array}$ & $\begin{array}{c}0.26-0.27 \\
- \\
\end{array}$ & $\begin{array}{l}2 \\
1 \\
\end{array}$ & $11, \mathrm{~B}$ & 21 \\
\hline $\begin{array}{l}\text { Dolerocypria } \\
\quad \text { mukaishimensis }\end{array}$ & & 0.67 & $0.65-0.68$ & 0.27 & $0.23-0.30$ & 10 & 0.21 & $0.19-0.22$ & 4 & $\begin{array}{c}11,14,21,24 \\
25, \mathrm{~A}, \mathrm{~B}\end{array}$ & $11-19$ \\
\hline $\begin{array}{l}\text { Perissocytheridea? } \\
\text { japonica }\end{array}$ & $\begin{array}{l}\text { Male } \\
\text { Female }\end{array}$ & $\begin{array}{l}0.67 \\
0.60\end{array}$ & $\begin{array}{l}0.64-0.69 \\
0.57-0.63 \\
\end{array}$ & $\begin{array}{l}0.31 \\
0.32\end{array}$ & $\begin{array}{l}0.29-0.32 \\
0.29-0.34\end{array}$ & $\begin{array}{l}10 \\
10\end{array}$ & $\begin{array}{l}0.33 \\
0.33\end{array}$ & $\begin{array}{l}0.30-0.38 \\
0.32-0.35\end{array}$ & $\begin{array}{l}10 \\
10\end{array}$ & $1,3,5$ & $19-28$ \\
\hline $\begin{array}{l}\text { Pontocythere } \\
\text { miurensis }\end{array}$ & $\begin{array}{l}\text { Male } \\
\text { Female }\end{array}$ & $\begin{array}{l}0.61 \\
0.56\end{array}$ & $\begin{array}{l}0.58-0.64 \\
0.53-0.57 \\
\end{array}$ & $\begin{array}{l}0.25 \\
0.26\end{array}$ & $\begin{array}{l}0.23-0.26 \\
0.23-0.30\end{array}$ & $\begin{array}{l}10 \\
10\end{array}$ & $\begin{array}{l}0.24 \\
0.25\end{array}$ & $\begin{array}{l}0.22-0.27 \\
0.24-0.27\end{array}$ & $\begin{array}{l}10 \\
10\end{array}$ & $3,5,6$ & $23-27$ \\
\hline $\begin{array}{r}\text { Pontocythere } \\
\text { xiphoidea }\end{array}$ & $\begin{array}{l}\text { Male } \\
\text { Female }\end{array}$ & $\begin{array}{l}0.53 \\
0.53 \\
\end{array}$ & $\begin{array}{l}0.47-0.62 \\
0.51-0.56\end{array}$ & $\begin{array}{l}0.20 \\
0.22\end{array}$ & $\begin{array}{l}0.18-0.23 \\
0.20-0.24 \\
\end{array}$ & $\begin{array}{r}6 \\
10 \\
\end{array}$ & $\begin{array}{l}0.18 \\
0.22\end{array}$ & $\begin{array}{l}0.17-0.19 \\
0.20-0.24\end{array}$ & $\begin{array}{r}6 \\
10 \\
\end{array}$ & $3,5,6$ & $23-27$ \\
\hline $\begin{array}{l}\text { Callistocythere } \\
\text { pumila }\end{array}$ & $\begin{array}{l}\text { Male } \\
\text { Female }\end{array}$ & $\begin{array}{c}0.48 \\
-\end{array}$ & $\begin{array}{l}- \\
-\end{array}$ & $\begin{array}{c}0.25 \\
-\end{array}$ & $\begin{array}{l}- \\
-\end{array}$ & 1 & $\begin{array}{c}0.18 \\
-\end{array}$ & $\begin{array}{l}- \\
-\end{array}$ & 1 & 5,6 & 27 \\
\hline $\begin{array}{l}\text { Ishizakiella } \\
\quad \text { miurensis }\end{array}$ & $\begin{array}{l}\text { Male } \\
\text { Female }\end{array}$ & $\begin{array}{l}0.56 \\
0.62\end{array}$ & $\begin{array}{l}0.53-0.58 \\
0.59-0.64\end{array}$ & $\begin{array}{l}0.28 \\
0.31\end{array}$ & $\begin{array}{l}0.26-0.29 \\
0.30-0.32\end{array}$ & $\begin{array}{l}10 \\
10\end{array}$ & $\begin{array}{l}0.23 \\
0.32\end{array}$ & $\begin{array}{l}0.22-0.24 \\
0.29-0.34\end{array}$ & $\begin{array}{r}10 \\
2\end{array}$ & $\begin{array}{c}1,3,5,6,11 \\
11^{\prime}, 12,14 \\
18,21,24,25 \\
\text { A, B, F } \\
\end{array}$ & $3-25$ \\
\hline $\begin{array}{l}\text { Palusleptocythere } \\
\text { migrans }\end{array}$ & $\begin{array}{l}\text { Male } \\
\text { Female }\end{array}$ & $\begin{array}{l}0.40 \\
0.40\end{array}$ & $\begin{array}{l}0.39-0.41 \\
0.38-0.41 \\
\end{array}$ & $\begin{array}{l}0.22 \\
0.24 \\
\end{array}$ & $\begin{array}{l}0.21-0.23 \\
0.22-0.25\end{array}$ & $\begin{array}{l}10 \\
10 \\
\end{array}$ & $\begin{array}{l}0.16 \\
0.17 \\
\end{array}$ & $\begin{array}{l}0.15-0.17 \\
0.17-0.18 \\
\end{array}$ & $\begin{array}{l}10 \\
10\end{array}$ & $21,24, \mathrm{~B}$ & $6-24$ \\
\hline $\begin{array}{c}\text { Spinileberis } \\
\text { pulchra }\end{array}$ & $\begin{array}{l}\text { Male } \\
\text { Female }\end{array}$ & $\begin{array}{l}0.59 \\
0.63 \\
\end{array}$ & $\begin{array}{l}0.58-0.60 \\
0.57-0.67 \\
\end{array}$ & $\begin{array}{l}0.32 \\
0.37\end{array}$ & $\begin{array}{l}0.32-0.33 \\
0.35-0.39 \\
\end{array}$ & $\begin{array}{c}2 \\
10 \\
\end{array}$ & $\begin{array}{l}0.23 \\
0.31 \\
\end{array}$ & $\begin{array}{l}0.22-0.24 \\
0.29-0.34 \\
\end{array}$ & $\begin{array}{r}2 \\
10 \\
\end{array}$ & $14,21, \mathrm{~A}, \mathrm{~B}$ & $2-24$ \\
\hline $\begin{array}{l}\text { Spinileberis } \\
\quad \text { quadriaculeata }\end{array}$ & $\begin{array}{l}\text { Male } \\
\text { Female }\end{array}$ & $\overline{0.54}$ & $\begin{array}{l}- \\
- \\
\end{array}$ & $\overline{0.34}$ & - & $\overline{1}$ & $0 . \overline{30}$ & - & $\overline{1}$ & $7^{\prime}$ & $24<$ \\
\hline $\begin{array}{l}\text { Aurila } \\
\quad \text { disparata }\end{array}$ & $\begin{array}{l}\text { Male } \\
\text { Female }\end{array}$ & $\begin{array}{c}0.69 \\
-\end{array}$ & - & $\begin{array}{c}0.56 \\
-\end{array}$ & $\begin{array}{l}- \\
-\end{array}$ & $\begin{array}{c}1 \\
-\end{array}$ & - & $\begin{array}{l}- \\
-\end{array}$ & $\begin{array}{l}- \\
-\end{array}$ & 18 & - \\
\hline $\begin{array}{c}\text { Robustaurila } \\
\text { ishizakii }\end{array}$ & $\begin{array}{l}\text { Male } \\
\text { Female } \\
\end{array}$ & $\begin{array}{c}0.64 \\
- \\
\end{array}$ & $\begin{array}{l}- \\
- \\
\end{array}$ & $\begin{array}{c}0.38 \\
- \\
\end{array}$ & $\begin{array}{l}- \\
- \\
\end{array}$ & $\begin{array}{c}1 \\
- \\
\end{array}$ & $\begin{array}{l}- \\
- \\
\end{array}$ & $\begin{array}{l}- \\
- \\
\end{array}$ & $\begin{array}{l}- \\
- \\
\end{array}$ & 5 & - \\
\hline $\begin{array}{c}\text { Bicornucythere } \\
\text { bisanensis }\end{array}$ & $\begin{array}{l}\text { Male } \\
\text { Female }\end{array}$ & $\begin{array}{l}0.88 \\
0.84 \\
\end{array}$ & $\begin{array}{l}- \\
- \\
\end{array}$ & $\begin{array}{l}0.54 \\
0.55 \\
\end{array}$ & $\begin{array}{l}- \\
- \\
\end{array}$ & $\begin{array}{l}1 \\
1 \\
\end{array}$ & $\begin{array}{l}- \\
- \\
\end{array}$ & $\begin{array}{l}- \\
- \\
\end{array}$ & $\begin{array}{l}- \\
- \\
\end{array}$ & $5,6,18$ & - \\
\hline $\begin{array}{l}\text { Angulicytherura? } \\
\text { miii }\end{array}$ & $\begin{array}{l}\text { Male } \\
\text { Female } \\
\end{array}$ & $\begin{array}{l}0.62 \\
0.54 \\
\end{array}$ & $\begin{array}{l}0.59-0.67 \\
0.51-0.56 \\
\end{array}$ & $\begin{array}{l}0.30 \\
0.28 \\
\end{array}$ & $\begin{array}{l}0.29-0.32 \\
0.26-0.29 \\
\end{array}$ & $\begin{array}{l}10 \\
10\end{array}$ & $\begin{array}{l}0.28 \\
0.27 \\
\end{array}$ & $\begin{array}{l}0.27-0.29 \\
0.24-0.28 \\
\end{array}$ & $\begin{array}{l}10 \\
10\end{array}$ & $\begin{array}{l}1,11,11^{\prime}, \\
24,25, \mathrm{~B}\end{array}$ & $4-23$ \\
\hline $\begin{array}{c}\text { Hemicytherura } \\
\text { tricarinata }\end{array}$ & $\begin{array}{l}\text { Male } \\
\text { Female }\end{array}$ & $\begin{array}{c}0.36 \\
- \\
\end{array}$ & $\begin{array}{l}- \\
- \\
\end{array}$ & $\begin{array}{c}0.2 \\
- \\
\end{array}$ & $\begin{array}{l}- \\
- \\
\end{array}$ & $\begin{array}{c}1 \\
-\end{array}$ & - & $\begin{array}{l}- \\
-\end{array}$ & $\begin{array}{l}- \\
-\end{array}$ & 6 & - \\
\hline Hemicytherura sp. & $\begin{array}{l}\text { Male } \\
\text { Female }\end{array}$ & $\begin{array}{c}0.37 \\
- \\
\end{array}$ & $\begin{array}{c}0.37-0.38 \\
- \\
\end{array}$ & $\begin{array}{c}0.22 \\
-\end{array}$ & $\begin{array}{c}0.22-0.22 \\
-\end{array}$ & $\begin{array}{l}2 \\
-\end{array}$ & $\begin{array}{l}- \\
-\end{array}$ & $\begin{array}{l}- \\
- \\
-\end{array}$ & - & 18 & - \\
\hline $\begin{array}{l}\text { Semicytherura } \\
\text { wakamurasaki }\end{array}$ & $\begin{array}{l}\text { Male } \\
\text { Female }\end{array}$ & $\begin{array}{l}0.36 \\
0.35 \\
\end{array}$ & $\begin{array}{l}- \\
- \\
\end{array}$ & $\begin{array}{l}0.18 \\
0.19\end{array}$ & $\begin{array}{l}- \\
- \\
\end{array}$ & $\begin{array}{l}1 \\
1\end{array}$ & $\begin{array}{l}0.16 \\
0.16\end{array}$ & - & $\begin{array}{l}1 \\
1\end{array}$ & $5,6,18$ & $23-27$ \\
\hline $\begin{array}{c}\text { Loxoconcha } \\
\text { kosugii }\end{array}$ & $\begin{array}{l}\text { Male } \\
\text { Female }\end{array}$ & $\begin{array}{l}0.66 \\
0.55\end{array}$ & $\begin{array}{l}0.61-0.69 \\
0.52-0.58\end{array}$ & $\begin{array}{l}0.35 \\
0.34\end{array}$ & $\begin{array}{l}0.32-0.37 \\
0.32-0.35\end{array}$ & $\begin{array}{l}10 \\
10\end{array}$ & $\begin{array}{l}0.33 \\
0.29\end{array}$ & $\begin{array}{l}0.30-0.36 \\
0.27-0.32\end{array}$ & $\begin{array}{l}10 \\
10\end{array}$ & $\begin{array}{c}1,3,5,6,11 \\
11^{\prime}, 14,12 \\
18,21,24,25 \\
\quad \text { A, B, F }\end{array}$ & $16-28$ \\
\hline $\begin{array}{c}\text { Loxoconcha } \\
\text { pulchra }\end{array}$ & $\begin{array}{l}\text { Male } \\
\text { Female }\end{array}$ & $\begin{array}{l}0.61 \\
0.49\end{array}$ & $\begin{array}{l}0.59-0.61 \\
0.46-0.50\end{array}$ & $\begin{array}{l}0.35 \\
0.33\end{array}$ & $\begin{array}{l}0.34-0.35 \\
0.31-0.34\end{array}$ & $\begin{array}{l}10 \\
10\end{array}$ & $\begin{array}{l}0.32 \\
0.28\end{array}$ & $\begin{array}{l}0.31-0.33 \\
0.27-0.31\end{array}$ & $\begin{array}{l}10 \\
10\end{array}$ & $\begin{array}{c}1,3,5,6,12 \\
18,21,24 \\
\text { A, F }\end{array}$ & $21-28$ \\
\hline $\begin{array}{r}\text { Cytheromorpha } \\
\text { acupunctata }\end{array}$ & $\begin{array}{l}\text { Male } \\
\text { Female }\end{array}$ & $\begin{array}{l}0.64 \\
0.55 \\
\end{array}$ & - & $\begin{array}{l}0.28 \\
0.28\end{array}$ & $\begin{array}{l}- \\
- \\
\end{array}$ & $\begin{array}{l}1 \\
1 \\
\end{array}$ & $\begin{array}{l}0.22 \\
0.22 \\
\end{array}$ & $\begin{array}{l}- \\
- \\
\end{array}$ & $\begin{array}{l}1 \\
1\end{array}$ & 6 & 27 \\
\hline $\begin{array}{r}\text { Cytherois } \\
\text { ikeyai }\end{array}$ & $\begin{array}{l}\text { Male } \\
\text { Female }\end{array}$ & $\begin{array}{l}0.26 \\
0.29\end{array}$ & $\begin{array}{l}0.25-0.28 \\
0.28-0.30\end{array}$ & $\begin{array}{l}0.11 \\
0.13\end{array}$ & $\begin{array}{l}0.09-0.12 \\
0.13-0.14\end{array}$ & $\begin{array}{l}10 \\
10\end{array}$ & $\begin{array}{c}0.1 \\
0.13\end{array}$ & $\begin{array}{l}0.09-0.12 \\
0.12-0.13\end{array}$ & $\begin{array}{l}10 \\
10\end{array}$ & $\begin{array}{c}3,5,11,11^{\prime} \\
21, \mathrm{~B}, \mathrm{~F}\end{array}$ & $15-27$ \\
\hline
\end{tabular}


remains unknown. It is expected that the intertidal fauna (shallower than $5 \mathrm{~m}$ ) should be different from that of an inner bay environment. Frydl (1982) did not use any inventories of ostracods from estuarine environments in his reconstructions of the paleoenvironment of the Japanese Holocene. Besides Frydl's work, the common species listed above have been reported recently from other Holocene deposits (e.g., Tsukagoshi et al. 1994; Irizuki et al. 1998, 1999; Fujiwara et al. 2000; Irizuki and Hosoyama 2000); however, those assemblages were not interpreted as estuarine.

More recently, analysis of Holocene deposits using "sequence stratigraphy" has resulted in an increased interest in non-marine and brackish-water deposits. It is critical to take the estuarine environment, situated between sea and land, into consideration in detailed paleoenvironmental interpretation of Holocene deposits and estimation of associated sea-level fluctuations. When fossil ostracods from such estuarine deposits are reported, the present study may provide a guide to paleoenvironmental reconstruction.

In 1997 an express way, the "Tokyo Bay Aqualine" connecting the west and east sides of Tokyo Bay, was completed. The eastern half of the highway is a bridge that passes within $2 \mathrm{~km}$ of the present study area, while the remainder of the road progresses via a long undersea tunnel. The effect of the "Aqualine" highway on the estuarine environment of Tokyo Bay is not yet known, but sediments containing ostracods from this study area have been collected since the latter half of the 1980s and analysis of the ostracod faunal associations may facilitate monitoring of changing environments over the past decade and into the future. In order to use ostracods in biomonitoring, the seasonal population dynamics of key indicator species must be understood, and the present study represents the first step towards that end.

\section{Acknowledgments}

The authors express their sincere thanks to Dr. David Horne (University of Greenwich) for his critical reading of the manuscript and valuable advice. Gratitude is also expressed to Prof. Kunihiko Endo and the late Dr. Masato Kosugi (Nihon University) for their introduction to the natural history of the Obitsu River Estuary, their valuable suggestions, and continual encouragement. Deep appreciation is due, furthermore, for many suggestions received from Prof. Noriyuki Ikeya (Shizuoka University), Dr. Karel Wouters (Institut Royal des Sciences Naturelles de Belgique), Dr. Robin Smith (Kanazawa University), Dr. Toshiaki Irizuki (Aichi University of Education), and Mr. Naohiro Sato and Mr. Yusaku Kaseda (Shizuoka University). The authors also greatly appreciate Dr. M. Satish-Kumar (Shizuoka University) for reading this manuscript. Mr. Kazuo Takashina (Kisarazu City, Chiba Prefecture) and the Fishermen's Cooperative of Kuzuma, Chiba Prefecture, provided various facilities to the authors.

This study was partly supported by funds provided by the Nippon Life Insurance Foundation (in 1998-1999) and a Grant-in-Aid for Scientific Research (No. 04740443) from the Ministry of Education, Science and Culture, Government of Japan. 


\section{References}

Abe, K. 1983. Population structure of Keijella bisanensis (Okubo) (Ostracoda, Crustacea)-An inquiry into how far the population structure will be preserved in the fossil record. Journal of the Faculty of Science, the University of Tokyo, Section 2, 20: 443-488.

Abe, K. 1985. [Ostracoda, small organisms on sandy mud bottom]. Iden (The Heredity) 39: 3238. [In Japanese]

Bodergat, A. M. and Ikeya, N. 1988. Distribution of Recent Ostracoda in Ise and Mikawa Bays, Pacific coast of central Japan. Pp. 413-428. In: Hanai, T., Ikeya, N. and Ishizaki, K. (Eds) Evolutionary Biology of Ostracoda (Proceedings of the 9th International Symposium on Ostracoda). Kodansha, Tokyo, $1356 \mathrm{pp}$.

Brady, G. S. 1880. Report on the Ostracoda dredged by H. M. S. Challenger, during the years 1873-1876. Report on the Scientific Results of the Voyage of H. M. S. Challenger, Zoology 1: $1-184$.

Frydl, P. M. 1982. Holocene ostracods in the southern Boso Peninsula. The University Museum, the University of Tokyo, Bulletin (20): 61-140.

Fujiwara, O., Masuda, F., Sakai, T., Irizuki, T. and Fuse, K. 2000. Tsunami deposits in Holocene bay mud in southern Kanto region, Pacific coast of central Japan. Sedimentary Geology 135: 219-230.

Hanai, T. 1957a. Studies on the Ostracoda from Japan. I. Family Leptocytheridae, new subfamily. Journal of the Faculty of Science, The University of Tokyo, Section 2, 10: 431-468.

Hanai, T. 1957b. Studies on the Ostracoda from Japan. III. Subfamilies Cytherurinae G. W. Müller (emend. G. O. Sars, 1925) and Cytheropterinae n. subfam. Journal of the Faculty of Science, the University of Tokyo, Section 2, 11: 11-36.

Hanai, T. 1959. Studies on the Ostracoda from Japan. IV. Family Cytherideidae Sars, 1925. Journal of the Faculty of Science, the University of Tokyo, Section 2, 11: 291-308.

Hanai, T. 1961a. Studies on the Ostracoda from Japan: hingement. Journal of the Faculty of Science, the University of Tokyo, Section 2, 13: 345-377.

Hanai, T. 1961b. Spinileberis, a new genus of Ostracoda from the Pacific. Transactions and Proceedings of the Palaeontological Society of Japan (44): 167-170.

Hanai, T., Ikeya, N., Ishizaki, K., Sekiguchi, Y. and Yajima, M. 1977. Checklist of Ostracoda from Japan and its adjacent seas. The University Museum, the University of Tokyo, Bulletin 12: 1-119.

Hiruta, S. 1981. Methods in the studies of Recent Ostracoda. 1. Collecting and preparation of specimens. Seibutsu Kyouzai (Materials of Biology) (16): 5-24. [In Japanese]

Hiruta, S. and Smith, R. 2001. Living freshwater and shallow marine Ostracoda in eastern Hokkaido, Japan. Pp. 107-125. In: Ikeya, N. (Ed.) Guidebook of Excursions. Organizing Committee of the 14th International Symposium on Ostracoda, Shizuoka, $147 \mathrm{pp}$.

Hou, Y.-T., Chen, T.-C., Yang, H.-R., Ho, J.-D., Zhou, Q.-C. and Tian, M.-Q. 1982. CretaceousQuaternary Ostracode Fauna from Jiungsu. Beijing, 386 pp. [In Chinese with English summary]

Huh, M. 1992. Miocene Ostracoda from the Songjeon Formation in the Eoil Basin, Korea. Thesis Collection of Chonnam University (Natural Sciences) (37): 57-65.

Huh, M. and Paik, K.-H. 1992. Miocene Ostracoda from the Pohang Basin, Korea. Paleontological Society of Korea, Special Publication (1): 101-119.

Ikeya, N. 1982. Cenozoic Crustacea (Ostracoda). Pp. 374-379. In: Hujiyama, E., Hamada, T. and Yamagiwa, N. (Eds) An Illustrated Book of Japanese Fossils for Students. Hokuryukan, Tokyo, 574 pp. [In Japanese] 
Ikeya, N. 1983. The ostracodes deposited in the Hancock Museum, Newcastle-upon-Tyne, collected from the Yokohama Harbor and the Coast of Misaki. Kanagawa Prefecture, Natural History Material 4: 1-6. [In Japanese]

Ikeya, N. 1993. [Characteristics of inner bay Ostracoda from Japan]. Urban Kubota (32): 26-29. [In Japanese]

Ikeya, N. 1995. Ostracoda in sediment cores from Yokohama Port. Report of Yokohama Environmental Research Institute (116): 27-33. [In Japanese]

Ikeya, N. and Hamada, H. 1990. On Robustaurila ishizakii (Okubo). Stereo-Atlas of Ostracod Shells 17: 137-144.

Ikeya, N. and Hanai, T. 1982. Ecology of Recent ostracods in the Hamana-ko region, the Pacific coast of Japan. The University Museum, the University of Tokyo, Bulletin (20): $15-59$.

Ikeya, N., Hasegawa, H. and Kashima, T. 1987. [Analysis of fossil Ostracoda-Holocene ostracode assemblage in the downtown of Kawasaki City (Kanagawa Prefecture)]. Pp. 51-64. In: Matsushima, Y. (Ed.) The Geological Studies on the Alluvium Deposits in the Tama and Tsurumi Rivers Lowland, Kawasaki. Kawasaki City Museum, Kawasaki, 146 pp. [In Japanese]

Ikeya, N. and Itoh, H. 1991. Recent Ostracoda from the Sendai Bay region, Pacific coast of northern Japan. Reports of Faculty of Science, Shizuoka University (25): 93-145.

Ikeya, N., Okubo, I., Kitazato, H. and Ueda, H. 1985. Shizuoka (Pleistocene and living Ostracoda, shallow marine, brackish and fresh water), Exc. 4. Pp. 1-32. In: Organizing Committee of 9th International Symposium on Ostracoda (Eds) Guidebook of Excursions. Organizing Committee of the 9th International Symposium on Ostracoda, Shizuoka, $113 \mathrm{pp}$.

Ikeya, N., Shimura, K. and Iwasaki, Y. 1995. Ecology and adaptation of the genus Spinileberis in the North Pacific. Pp. 389-397. In: Ríha, J. (Ed.) Ostracoda and Biostratigraphy. A. A. Balkema, Rotterdam, Brookfield, 454 pp.

Ikeya, N and Shiozaki, M. 1993. Characteristics of the inner bay ostracodes around the Japanese islands-The use of ostracodes to reconstruct paleoenvironments. Memoirs of the Geological Society of Japan (39): 15-32. [In Japanese with English abstract]

Ikeya, N. and Ueda, H. 1988. Morphological variations of Cytheromorpha acupunctata (Brady) in continuous population at Hamana-ko Bay, Japan. Pp. 319-340. In: Hanai, T., Ikeya, N. and Ishizaki, K. (Eds) Evolutionary Biology of Ostracoda (Proceedings of the 9th International Symposium on Ostracoda). Kodansha, Tokyo, 1356 pp.

Ikeya, N., Zhou, B.-C. and Sakamoto, J. 1992. Modern ostracode fauna from Otsuchi Bay, the Pacific coast of northeastern Japan. Pp. 339-354. In: Ishizaki, K. and Saito, T. (Eds) Centenary of Japanese Micropaleontology. Terra Scientific, Tokyo, $480 \mathrm{pp}$.

Irizuki, T., Fujiwara, O. and Fuse, K. 1999. Taphonomy of fossil ostracode assemblages in Holocene deposits on the Miura Peninsula, central Japan. Memoirs of the Geological Society of Japan (54): 99-116. [In Japanese with English abstract]

Irizuki, T., Fujiwara, O., Fuse, K. and Masuda, F. 1998. Paleoenvironmental changes during the last post glacial period on the western coast of the Miura Peninsula, Kanagawa Prefecture, central Japan: Fossil ostracode fauna and event deposits in bore hole cores. Kaseki (Fossils) (64): 1-22. [In Japanese with English abstract]

Irizuki, T. and Hosoyama, M. 2000. Fossil ostracodes (Crustacea) from the Pleistocene Noma Formation, Aichi Prefecture, central Japan. Bulletin of Aichi University of Education (49): 9-15. [In Japanese with English abstract]

Irizuki, T. and Matsubara, T. 1994. Vertical changes of depositional environments of the Lower to Middle Miocene Kadonosawa Formation based on analyses of fossil ostracode 
faunas. Journal of the Geological Society of Japan 100: 136-149. [In Japanese with English abstract]

Ishizaki, K. 1968. Ostracodes from Uranouchi Bay, Kochi Prefecture, Japan. Science Reports of the Tohoku University, Sendai, Second Series (Geology) 40: 1-45.

Ishizaki, K. 1969. Ostracodes from Shinjiko and Nakanoumi, Shimane Prefecture, western Honshu, Japan. Science Reports of the Tohoku University, Sendai, Second Series (Geology) 41: 197-224.

Ishizaki, K. 1971. Ostracodes from Aomori Bay, Aomori Prefecture, northeast Honshu, Japan. Science Reports of the Tohoku University, Sendai, Second Series (Geology) 43: 59-97.

Ishizaki, K. 1972. Morphological variation of Legminocythereis hodgii (Brady), Ostracoda (Crustacea), from Japan. Pp. 697-707. In: Hatai, K., Asano, K., Kitamura, N., Kotaka, T., Takayanagi, Y. and Nakagawa, H. (Eds) Prof. Jun-ichi Iwai Memorial Volume. Sasaki Publication Printing, Sendai, 728 pp.

Ishizaki, K. 1975. Morphological variation in Legminocythereis? hodgii (Brady), Ostracoda (Crustacea), from Japan. Bulletin of American Paleontology 65: 265-262.

Ishizaki, K. 1976. Ostracoda. Pp. 1-53. In: Asano, K. (Ed.) Micopaleontology (3). Asakura Book, Tokyo, 190 pp. [In Japanese]

Ishizaki, K. 1984. Detailed survey on ostracods in the drilling No. 56-9 core samples at the Kansai International Airport in Osaka Bay. Pp. 37-43. In: Nakaseko, K. (Ed.) Geological Survey of the Submarine Strata at the Kansai International Airport in Osaka Bay, Central Japan. The Calamity Science Institute, Osaka, 285 pp. [In Japanese]

Ishizaki, K. 1990. Sea level change in Mid-Pleistocene time and effects on Japanese ostracode faunas. Bulletin of Marine Science 47: 213-220.

Ishizaki, K. and Irizuki, T. 1990. Distribution of bathyal ostracodes in sediments of Toyama Bay, Central Japan. Courier Forschungsinstitut Senckenberg (123): 53-67.

Ishizaki, K., Irizuki, T. and Sasaki, O. 1993. Cobb Mountain spike of the Kuroshio Current detected by Ostracoda in the lower Omma Formation (Early Pleistocene), Kanazawa City, central Japan: analysis of depositional environments. Pp. 315-334. In: McKenzie, K. G. and Jones, P. J. (Eds) Ostracoda in the Earth and Life Sciences (Proceedings of the 11th International Symposium on Ostracoda). A. A. Balkema, Rotterdam, 724 pp.

Ishizaki, K. and Kato, M. 1976. The basin development of the Diluvium Furuya Mud Basin, Shizuoka Prefecture, Japan, based on faunal analysis of fossil ostracodes. Pp. 118-143. In: Takayanagi, Y. and Saito, T. (Eds) Progress in Micropaleontology. The American Museum of Natural History, New York, $422 \mathrm{pp}$.

Ishizaki, K. and Matoba, Y. 1985. Akita (Early Pleistocene cold, shallow water Ostracoda), Excursion 5. Pp. 1-12. In: Organizing Committee of 9th International Symposium on Ostracoda (Ed.) Guidebook of Excursions. Organizing Committee of the 9th International Symposium on Ostracoda, Shizuoka, $113 \mathrm{pp}$.

Kajiyama, E. 1913. [On the Ostracoda from Misaki, Part 3]. Doubutsugaku Zasshi 25: 1-16. [In Japanese]

Kamiya, T. 1988. Morphological and ethological adaptations of Ostracoda to microhabitats in Zostera beds. Pp. 303-318. In: Hanai, T., Ikeya, N. and Ishizaki, K. (Eds) Evolutionary Biology of Ostracoda (Proceedings of the 9th International Symposium on Ostracoda). Kodansha, Tokyo, $1356 \mathrm{pp}$.

Kamiya, T. 1989. Functional morphology of Ostracoda in seagrass beds-with special reference to the copulatory behavior. Benthos Research (35/36): 75-88. [In Japanese with English abstract]

Kamiya, T. and Nakagawa, T. 1993. Ostracode fossil assemblages in the Holocene shell bed 
found in Takahama-cho, Fukui Prefecture, central Japan. Monograph of the Fukui City Museum, Natural History (1): 115-33. [In Japanese with English abstract]

Kamiya, T., Ozawa, H. and Kitamura, A. 1996. Paleo-water mass structure during the deposition of middle part of the Omma Formation based on the change of ostracode assemblage. Hokuriku Geological Institution Report (5): 145-165. [In Japanese with English abstract]

Lee, E.-H. 1990. Pleistocene Ostracoda from the Marine Sedimentary Strata of the Cheju Islands, Korea. Ph.D Thesis., Department of Geology, Graduate School, Korea University, 400 pp., 36 pls.

Nohara, T. and Tabuki, R. 1985. Okinawa Island (Plio-Pleistocene tropical and subtropical Ostracoda, and Ostracoda of Recent coral reef), Excursion 6. Pp. 1-27. In: Organizing Committee of 9th International Symposium on Ostracoda (Ed.) Guidebook of Excursions. Organizing Committee of the 9th International Symposium on Ostracoda, Shizuoka, $113 \mathrm{pp}$.

Okada, Y. 1981. Development of cell arrangement in ostracod carapaces. Paleobiology 7: 276280.

Okada, Y. 1982a. Ultrastructure and pattern of the carapace of Bicornucythere bisanensis (Ostracoda, Crustacea). The University Museum, the University of Tokyo, Bulletin (20): 229255.

Okada, Y. 1982b. Structure and cuticle formation of the reticulated carapace of the ostracode Bicornucythere bisanensis. Lethaia 15: 85-101.

Okubo, I. 1974. Freshwater Ostracoda from Japan, XI. Ilyocypris angulata Sars, 1903. Research Bulletin of Shujitsu Junior College (4): 46-50.

Okubo, I. 1975. Callistocythere pumila Hanai, 1957 and Leguminocythereis bisanensis sp. nov. in the Inland Sea, Japan (Ostracoda). Proceedings of the Japanese Society of Systematic Zoology (11): 23-31.

Okubo, I. 1977. Cushmanidea subjaponica Hanai, 1959, in the Inland Sea, Japan. Research Bulletin of Shujitsu Junior College (7) 133-140.

Okubo, I. 1978. Two species of the family Cytheridae (Ostracoda) in the Inland Sea, Japan. Research Bulletin of Shujitsu Junior College (8): 89-98.

Okubo, I. 1979. Five species of Callistocythere (Ostracoda) from the Inland Sea of Seto. Researches on Crustacea (9): 13-25.

Okubo, I. 1980a. Six species of the subfamily Cytherurinae Müller, 1984, in the Inland Sea, Japan (Ostracoda). Publications of the Seto Marine Biological Laboratory 25: 7-26.

Okubo, I. 1980b. Three new species of the family Candonidae (Ostracoda) from the Inland Sea of Japan. Proceedings of the Japanese Society of Systematic Zoology 18: 17-26.

Okubo, I. 1980c. Taxonomic studies on Recent marine podocopid Ostracoda from the Inland Sea of Seto. Publications of the Seto Marine Biological Laboratory 25: 389-443.

Okubo, I. 1983. On the genus Perissocytheridea Stephenson, 1938, of Japan. Research Bulletin of Shujitsu Women's College and Shujitsu Junior College (13): 403-410.

Okubo, I. 1988. On the Recent Aurila species from Japan. Pp. 135-144. In: Hanai, T., Ikeya, N. and Ishizaki, K. (Eds) Evolutionary Biology of Ostracoda (Proceedings of the 9th International Symposium on Ostracoda). Kodansha, Tokyo, $1356 \mathrm{pp}$.

Okubo, I. 1991. Subclass Ostracoda Latreille, 1806. Pp. 98-125. In: Mizuno, T. and Takahashi, E. (Eds) An Illustrated Guide to Freshwater Zooplankton in Japan. Tokai University Press, Tokyo, $532 \mathrm{pp}$.

Ozawa, H. 1996. Ostracode fossils from the late Pliocene to early Pleistocene Omma Formation in the Hokuriku district, central Japan. Science Reports of Kanazawa University 41: $77-115$.

Paik, K.-H. and Lee, E.-H. 1988. Plio-Pleistocene ostracods from the Sogwipo Formation, Cheju 
Island, Korea. Pp. 541-556. In: Hanai, T., Ikeya, N. and Ishizaki, K. (Eds) Evolutionary Biology of Ostracoda (Proceedings of the 9th International Symposium on Ostracoda). Kodansha, Tokyo, $1356 \mathrm{pp}$.

Petkovski, T. and Keyser, D. 1992. Leptocythere ostrovskensis sp. n. (Crustacea, Ostracoda, Cytheracea) aus dem See Vegoritis (Ostrovsko Ezero) in NW Griechenland.-Mit kurzer Übersicht der Süsswasserarten des Genus Leptocythere G. O. Sars, 1925 vom Westbalkan. Mitteilungen aus dem Hamburgischen Zoologischen Museum und Institut 89: 227-237.

Schornikov, E. I. and Dolgov, G. V. 1995. Angulicytherura gen. n.-a new ostracod genus of the family Cytheruridae from Far-Eastern Seas. Biologiya Morya 21: 29-36. [In Russian with English abstract]

Schornikov, E. I. and Shaytarov, S. V. 1979. A new genus of ostracods from Far-Eastern Seas. Biologiya Morya 2: 41-47. [In Russian with English abstract]

Stephenson, M. B. 1938. Miocene and Pliocene Ostracoda of the genus Cytheridea from Florida. Journal of Paleontology 12: 127-148.

Takayasu, K., Ueda, K. and Ohta, H. 1990. Natural history of the Nakano-umi and Shinji Lakes -XII. Ostracode thanatocoenoces from the bottom deposits of Lake Nakano-umi and their historical distribution. Geological Reports of Shimane University (9): 129-144. [In Japanese with English abstract]

Tanaka, G., Seto, K. and Takayasu, K. 1998. The relationship between environments and ostracode assemblages from Miho Bay to Lake Shinji. Laguna (5): 81-91. [In Japanese with English abstract]

Tsukagoshi, A. 1992. [Lagoonal Ostracoda, Ishizakiella pacifica (Hanai)]. Newsletter of the University Museum, the University of Tokyo (26): 5. [In Japanese]

Tsukagoshi, A. 1994. Natural history of the brackish-water ostracode genus Ishizakiella from East Asia: evidence for heterochrony. Journal of Crustacean Biology 14: 295-313.

Tsukagoshi, A. 1998. On Callistocythere pumila Hanai, 1957. Stereo-Atlas of Ostracod Shells 25: 9-16.

Tsukagoshi, A. and Kamiya, T. 1996. Heterochrony of the ostracod hingement and its significance for taxonomy. Biological Journal of the Linnean Society 57: 343-370.

Tsukagoshi, A., Kosugi, M., Kurosawa, K., Matsunaga, M., Momoi, S. and Nakao, Y. 1994. Holocene environmental history in the Paleo-Nagareyama Bay, Central Japan. Science Report of the Matsudo Museum (2): 19-61. [In Japanese]

Tsukagoshi, A. and Parker, A. R. 2000. Trunk segmentation of some podocopine lineages in Ostracoda. Hydrobiologia 419: 15-30.

Victor, R. and Fernando, C. H. 1980. Ilyocypris dentifera Sars, 1903 versus Ilyocypris angulata Sars, 1903. A taxonomic study of two species of Ilyocypris Brady and Norman, 1889 (Crustacea, Ostracoda) described from China. Canadian Journal of Zoology 59: 1103-1110.

Wakamatsu, H. 1988. The genus Pontocythere (Ostracoda) from the Toshima Sand in Atsumi Peninsula, central Japan. Mizunami-City Fossil Museum, Scientific Report (14): 145-150. [In Japanese]

Wang, P.-X. and Bian, Y.-H. 1985. Foraminifera and Ostracoda in bottom sediments of the Bohai Gulf and their bearing on Quaternary paleoenvironments. Pp. 133-175. In: Wang, P.X. (Ed.) Marine Micropaleontology of China. China Ocean Press, Beijing, 370 pp.

Wang, P.-X., Min, Q.-B. and Yunhua, Y.-H. 1985. Distribution of Foraminifera and Ostracoda in bottom sediments of the northwestern part of the south Huanghai (Yellow) Sea and its geological significance. Pp. 93-132. In: Wang, P.X. (Ed.) Marine Micropaleontology of China. China Ocean Press, Beijing, 370 pp.

Wang, P.X., Hong, X.-Q. and Zhao, Q.-H. 1985. Living Foraminifera and Ostracoda: Distribu- 
tion in the coastal area of the East China Sea and the Huanghai Sea. Pp. 243-255. In: Wang, P.-X. (Ed.) Marine Micropaleontology of China. China Ocean Press, Beijing, $370 \mathrm{pp}$.

Wang, P.X., Zhang, J.-J., Zhao, Q.-H., Min, Q.-B., Bian, Y.-H., Zheng, L.-F., Cheng, X.-R. and Chen, R.-H. 1988. Foraminifera and Ostracoda in Bottom Sediments of the East China Sea. Ocean Press, Beijing. 438 pp. [In Chinese with English abstract]

Wang, P.-X. and Zhao, Q.-H. 1985. Ostracod distribution in bottom sediments of the East China Sea. Pp. 70-92. In: Wang, P.X. (Ed.) Marine Micropaleontology of China. China Ocean Press, Beijing, 370 pp.

Wang, Q. and Zhang, L.-X. 1987. Holocene ostracod fauna and paleoenvironment in the sea region around Hong Kong. Acta Oceanologica Sinica 6: 281-291.

Wang, Q., Li, Y., Tian, G. and Lin, F. 1988. Quaternary marine Ostracoda on the west coast of the Bohai Sea. Acta Oceanologica Sinica 7: 94-103.

Wouters, K. 1987. Range extension and supplementary description of Dolerocypria taalensis (Tressler) (Crustacea: Ostracoda). Indo-Malayan Zoology 4: 127-133.

Yajima, M. 1982. Late Pleistocene Ostracoda from the Boso Peninsula, central Japan. The University Museum, the University of Tokyo, Bulletin (20): 141-227.

Yajima, M. and Lord, A. 1990. The interpretation of Quaternary environments using Ostracoda: an example from Japan. Proceedings of Geological Association 101: 153-161.

Yajima, M, Hanai, T. and Ikeya, N. 1985. Ostracodes from Deep Sea Drilling Project Leg 87. Initial Reports of the Deep Sea Drilling Project 87: 605-608.

Yamaguchi, S. 2000. Phylogenetic and biogeographical history of the genus Ishizakiella (Crustacea, Ostracoda) inferred from mitochondrial COI gene sequences. Journal of Crustacean Biology 20: 357-384.

Yamane, K. 1998. Recent ostracode assemblages from Hiuchi-nada Bay, Seto Inland Sea of Japan. Bulletin of Ehime Prefecture Science Museum (3): 19-59. [In Japanese with English abstract]

Zhao, Q.-H. and Wang, P.-X. 1988. Distribution of modern Ostracoda in the shelf seas off China. Pp. 805-821. In: Hanai, T., Ikeya, N. and Ishizaki, K. (Eds) Evolutionary Biology of Ostracoda (Proceedings of the 9th International Symposium on Ostracoda). Kodansha, Tokyo, 1356 pp.

Zhao, Q.-H., Wang, P.-X. and Zhang, Q.-L. 1985. Ostracoda in bottom sediments of the South China Sea off Guangdong Province, China: their taxonomy and distribution. Pp. 196-217. In: Wang, P.-X. (Ed.) Marine Micropaleontology of China. China Ocean Press, Beijing, 370 pp.

Zheng, S.-Y. 1987. Quaternary Ostracoda fauna from coastal deposits along the coast of Fujian. Memories of Nanjing Institute of Geology and Palaeontology, Academia Sinica 23: 187-220. [In Chinese with English abstract] 